\title{
HOW RACE AND POVERTY INTERSECT TO PREVENT INTEGRATION: DESTABILIZING RACE AS A VEHICLE TO INTEGRATE NEIGHBORHOODS
}

\author{
Alex M. JOHNSON, JR.†
}

\section{INTRODUCTION}

The persistence of housing segregation in the face of legal and other societal efforts to promote integration has been the subject of intense academic debate and scholarship. Most of the "early" scholarship ${ }^{1}$ focused on the efficacy of the Fair Housing Act of 1968 and subsequent amendments. ${ }^{2}$ Much of the recent scholarship has focused on the failure of the Fair Housing Act to address the problem and the persistence of, indeed the increase in, residential segregation in the United States over the last twenty years. ${ }^{3}$ Although there are many theories explaining the persistence of

† Mary and Daniel Loughran Professor of Law, Harrison Foundation Research Professor of Law, University of Virginia School of Law; B.A. 1975, Claremont Men's College; J.D. 1978, U.C.L.A. School of Law.

' See, e.g., The FAIR Housing Act AFTER TwENTY YeARs (Robert G. Schwemm ed., 1989) (examining the effectiveness of the Fair Housing Act of 1968); GEORGE R. METCALF, FAIR HOUSING COMES OF AGE (1988) (assessing the results of fair housing activities and calling for more governmental support for fair housing); Jean $\mathbf{E}$. Dubofsky, Fair Housing: A Legislative History and a Perspective, 8 WASHBURN L.J. 149 (1969) (commenting on the legislative history of the newly passed Fair Housing Act); Arthur S. Flemming, The Politics of Fair Housing, 6 YALE L. \& POL'Y REV. 385, 386 (1988) (remarking that the Fair Housing Act "did not have the teeth it required if we were really going to deal with the issue of fair housing in a meaningful and effective way"); Leonard S. Rubinowitz \& Elizabeth Trosman, Affirmative Action and the American Dream: Implementing Fair Housing Policies in Federal Homeownership Programs, 74 Nw. U. L. REV. 491, $521-78$ (1979) (discussing the legal obligations arising under the affirmative action standard of the Fair Housing Act); Robert G. Schwemm, Private Enforcement and the Fair Housing Act, 6 YALE L. \& POL'Y REV. 375, 375 (1988) (posing the question, "[i]f the United States has been officially committed to providing for fair housing for the past 20 years, why is segregated housing still the prevailing norm throughout our nation?"); Richard H. Sander, Comment, Individual Rights and Demographic Realities: The Problem of Fair Housing, 82 Nw. U. L. REv. 874, 880-83 (1988) (describing the federal government's assault on housing discrimination via the Fair Housing Act as well as court decisions, but finding that each has had a minimal impact on racial segregation).

${ }^{2}$ Fair Housing Act of 1968, 42 U.S.C. $\$ \S 3601-3631$ (1988 \& Supp. V 1993).

${ }^{3}$ See DOUglas S. MASSEY \& NANCY A. DENTON, AMERICAN APARTHEID: SEGREGATION AND THE MAKING OF THE UNDERCLASS 186-216 (1993) (discussing the failure of the Fair Housing Act to eliminate residential segregation). American Apartheid is arguably the definitive work in this area of scholarship. 
residential racial segregation in contemporary American society, there is agreement that this problem has not improved ${ }^{4}$ since integration was adopted as a philosophy in the landmark case of Brown v. Board of Education. ${ }^{5}$

Although an exhaustive analysis of the reasons for the increase in residential segregation is outside the scope of this Article, it is beyond peradventure that racism and poverty are identified as two factors that contribute to the continuing existence of hypersegregation. ${ }^{6}$ Hypersegregation results in the creation of ghettos ${ }^{7}$ and other similarly designated neighborhoods in which the vast majority of urban Blacks ${ }^{8}$ live. This Article explores the interaction between

${ }^{4}$ See id. at $195-200$.

5347 U.S. 483 (1954) (Brown I). I make the uncontroversial assertion that Brown $I$ represented the end of one era in race relations, de jure segregation in education, and adopted an integrationist philosophy and approach to education that not only signaled the death knell of de jure segregation in education, but the philosophy of de jure segregation in toto. Brown I began the integrationist philosophy that inevitably led to the adoption of the Fair Housing Act of 1968 and the notion that segregated residential housing patterns were and are to be lawfully and socially discouraged. For a discussion of Brown I and its historical place in American judicature, see Michael J. Klarman, Brown, Racial Change, and the Civil Rights Movement, 80 VA. L. REV. 7 (1994) (discussing the long-term inevitability of racial change and the short-term significance of Brown $I$ ). For a discussion of integrationism and its impact on the educational choices available to Blacks, see Alex M. Johnson, Jr., Bid Whist, Tonk, and United States v. Fordice: Why Integrationism Fails African-Americans Again, 81 CAL. L. REV. $1401,1465-68$ (1993) (defending the existence of publicly financed, historically Black colleges).

${ }^{6}$ A study by Douglas Massey and Nancy Denton measured segregation along five dimensions-evenness, exposure, clustering, centralization, and concentration. See Douglas S. Massey \& Nancy A. Denton, Hypersegregation in U.S. Metropolitan Areas: Black and Hispanic Segregation Along Five Dimensions, 26 DEMOGRAPHY 373, 374, 389 (1989). The results of this study indicated that Blacks are the only minority group that experiences extreme segregation in all five dimensions. See id. at 374. Massey and Denton called this condition "hypersegregation." Id. Hypersegregation results in extreme social isolation and causes, among other things, a concentration of poverty, labor force withdrawal, and unemployment in inner-city Black neighborhoods. See id. at 389. For further discussion of this issue and a presentation of the statistics that demonstrate the existence of hypersegregation in housing patterns, see infra notes 37-41 and accompanying text.

"For a definition of "ghetto," see infra note 25.

${ }^{8}$ The current trend is to refer to Black Americans as Blacks. For the purposes of this Article, I will adopt Professor Neil Gotanda's position with respect to the usage of the terms "Black," "Negro," "African-American," and "white":

[Because] use of these words has varied historically, choosing between "Negro" and "Black" will generally follow the context of the historical discussion. "African-American" is used to emphasize the present necessity of a self-conscious re-examination of the Black American race, including a recognition of the dimensions of culture and community beyond the formal label.... 
racism and poverty and the effect this interaction has on the consignment of Blacks to segregated, substandard housing. My thesis, however, differs from those traditionally presented.

In Part I, I review the traditional scholarly explanations that focus on race and poverty to explain the increase in residential segregation. Next, I disconnect race and poverty and briefly explain the role that racism plays in maintaining segregated communities. This explication is based on the assumption that in a world without racism-the ideal state of race relations in which race would be treated no differently than eye color, and neither entitlements nor rights would depend on it $^{9}$-Blacks and whites would be proportionately represented in neighborhoods based on their socioeconomic status. Implicit in this assumption is a second assumption that Blacks would, all other things being equal, prefer to live in integrat-

The word "white" is not capitalized despite its use in this article as the dialectical opposite of Black. The terms "white" and "Black" evolved in the seventeenth century North American colonies as slavery evolved, but their meanings go far beyond that historical moment. To the extent that Black "summarizes" relations of racial subordination, white "summarizes" racial domination. As a term describing racial domination, "white" is better left in lower case, rather than privileged with a capital letter. "Black," on the other hand, has deep political and social meaning as a liberating term, and, therefore, deserves capitalization.

Neil Gotanda, A Critique of "Our Constitution Is Color-Blind", 44 STAN. L. REv. 1, 4 n.12 (1991).

More recently, Professor Cheryl Harris has joined Professor Kimberlé Crenshaw in using the term "Black": "I use the term 'Black' throughout the paper for the reasons articulated by Professor Kimberlé Crenshaw. I share her view that 'Blacks, like Asians, Latinos, and other "minorities," constitute a specific cultural group and, as such, require denotation as a proper noun." Cheryl I. Harris, Whiteness as Property, 106 HARV. L. REv. 1707, 1710 n.3 (1993) (quoting Kimberlé W. Crenshaw, Race, Reform, and Retrenchment: Transformation and Legitimation in Antidiscrimination Law, 101 HARV. L. REV. 1331, 1332 n.2 (1988)). Nikki Giovanni states more directly:

I am a black American. Period. The rest is of no particular interest to me. Afro-American, African American, whatever. I believe that if I remain a black American I force all others to become and claim their other Americanisms. They are white Americans, Irish-Americans, JewishAmericans, or whatever hyphens they would like to use. The' noun is "black"; American is the adjective.

Nikki Giovanni, Black Is the Noun, in LURE AND LOATHING: ESSAYS ON RACE, IDENTITY, AND THE AMBIVALENCE OF ASSIMILATION 113, 122 (Gerald Early ed., 1993) [hereinafter LURE AND LOATHING].

${ }^{9}$ See Richard A. Wasserstrom, Racism, Sexism, and Preferential Treatment: An Approach to the Topics, 24 UCLA L. REV. 581, 586 (1977) ("Race does not function in our culture as does eye color. Eye color is an irrelevant category; nobody cares what color people's eyes are; it is not an important cultural fact; nothing turns on what eye color you have."). 
ed communities with whites, ${ }^{10}$ but are precluded from doing so because they have historically been discriminated against and subordinated in American society. ${ }^{11}$

Part II analyzes the deficiencies of the "traditional" legal approaches to the eradication of discrimination in housing and its byproduct, segregation. In particular, I critique two competing models-the market model and the interventionist model. Proponents argue that these models can serve as vehicles to reduce or eliminate racial discrimination in housing. The market model decries the use of intervention or legal rules to alter discriminatory

${ }^{10}$ The notion that Blacks would want to live in integrated communities with whites if given a choice between equal housing in an integrated neighborhood or a neighborhood that is predominantly or exclusively Black represents the acceptance of integrationism as a philosophy and an ideal. Others have contended that integrationism is a failed philosophy or strategy for Blacks in that it represents either a form of assimilation that is the equivalent of painless genocide or an incorrect strategy to achieve racial harmony in American society because it requires Blacks to interact with whites from a position of weakness rather than strength, strength which can only be developed through strong, and largely separate, Black enclaves or communities within the society. See, e.g., Gary Peller, Race Consciousness, 1990 DukE L.J. 758, 783-811 (contrasting integrationism with black nationalism). This Article proceeds on an assumption that integrationism as a process and a goal is normatively positive for society. See, e.g., Johnson, supra note 5, at 1438-39 (discussing the distinction between integration as a goal and integration as a process).

Elsewhere, in the analogous context of postsecondary education, I take the position that although integration may be normatively positive for society and therefore something that should be encouraged, it should be recognized and accepted that positive benefits flow from maintaining segregated environments as long as those segregated environments, including housing, are freely chosen by Blacks. See id. at 1437. Thus, as long as Blacks have the choice to integrate previously all or predominantly white institutions, a societal good is produced. Whether they indeed choose to integrate is another question the answer to which is irrelevant for the issues presented herein.

"Although the focus of the paper is on Blacks, the argument may be expanded to other persons who are subordinated simply because they are not white. These subordinated persons have been collectively referred to as "outsiders" because they represent the "other" or those who are not white and therefore are not perceived to be the norm. For a discussion of the "outsider" and other subordinated persons, see Mari J. Matsuda, Public Response to Racist Speech: Considering the Victim's Story, 87 Mich. L. REv. 2320, 2323-26 (1989). Professor Matsuda employs the term "outsider" "in order to avoid 'minority'-a term that belies the numerical significance of the constituencies typically excluded from jurisprudential discourse." Id. at 2323 n.15. For a discussion of "otherness" and the dichotomy between "others" and "us" or "we," see Alex M. Johnson, Jr., Defending the Use of Narrative and Giving Content to the Voice of Color: Rejecting the Imposition of Process Theory in Legal Scholarship, 79 IOWA L. REV. 803, 832-34 (1994) (contending that the voice of color as "other" or "them," rather than as "same" or "us," forces minority scholars to embrace a perspectival approach in which issues are seen dichotomously from both an insider and outsider perspective). 
behavior and assumes that a perfect market will produce a perfect world, that is, one free of inefficient discrimination. ${ }^{12}$ Hence, the goal of market adherents is to design rules that produce a more perfect efficiency-maximizing market. To the contrary, the interventionist model assumes that discrimination will not be eradicated via market mechanisms and assumes that people adapt to legal rules and internalize them. Consequently, interventionists prescribe the adoption of antidiscrimination rules or regulations. Their goal is to create perfect default rules and regulations to combat discrimination.

Part II examines both of these models in light of the apparent failure of American society to reduce or eliminate residential housing segregation in any meaningful way. An examination of both theories reveals flaws that lessen their value as remedies for housing discrimination. Adopting a predictive or positivistic approach, I first demonstrate, as have others, that the market model may entrench rather than lessen segregation. In addition, this section reveals a paradox that explains why the market model fails to work in the discrete, fixed, one-shot transaction that is representative of the sale of a private residence, when accepted economic theory supports the contention that a seller of real property should be motivated to sell to the highest bidder, irrespective of race, if that seller is terminating her relationship with the land and the neighbors associated with it. On the contrary, the residential sale transaction should, to a degree, be viewed as a relational contract, $^{13}$ at least with respect to third-party effects. Those third-

${ }^{12}$ As noted below, however, the existence and operation of "efficient discrimination" exists, and its presence is one of the factors that leads to the continuation of discrimination. See infra note 77 and accompanying text.

${ }^{13}$ Charles Goetz and Robert Scott define a relational contract as follows:

A contract is relational to the extent that the parties are incapable of reducing important terms of the arrangement to well-defined obligations. Such definitive obligations may be impractical because of inability to identify uncertain future conditions or because of inability to characterize complex adaptations adequately even when the contingencies themselves can be identified in advance. ... [L]ong-term contracts are more likely than short-term agreements to fit this conceptualization, but temporal extension per se is not the defining characteristic.

Charles J. Goetz \& Robert E. Scott, Principles of Relational Contracts, 67 VA. L. REV. 1089,1091 (1981). Relational contracts differ from standard or complete contingent contracts because the complete contingent contract assumes complete risk allocation ex ante; in other words, performance standards are reduced to specific obligations. In the complete contingent contract, parties are assumed to be able to allocate all the risks ex ante, because they are presumed to have access to complete information 
party effects cause market failure and reinforce the discriminatory animus of the residential seller.

In contrast, the major flaw in the interventionist model is exposed through an analysis of its normative base. The interventionist model presupposes that the normative base that generates the antidiscrimination message or preference is uniform and accepted. I assert to the contrary that a significant failure of the interventionist model is the articulation of a uniform message that racism is unacceptable in contemporary American society. Part II demonstrates that the interventionist model is likely to continue to fail to remediate American society's racial issues in housing and elsewhere as long as fixed racial categorizations continue to be made and enforced in American society.

Consequently, in the last section of Part II, I assume that the interventionist model is viable, but point out that it is inconsistent because American society advocates an antidiscrimination norm through laws such as the Fair Housing Act, but simultaneously promotes racial distinctiveness through such policies as the "one drop of blood rule." 14 I conclude, given the history and power of racism in the United States, that neither the antidiscrimination principle nor the adaptive preference it encourages will ever fully be internalized into society as long as the historically prevalent racial distinctiveness paradigm is also promoted as an endogenous preference.

In Part III, I apply the insights of Parts I and II to current residential housing patterns in American society to explain why

about all the future contingencies and the relevant legal rules that could affect their relationship. See Charles J. Goetz \& Robert E. Scott, The Mitigation Principle: Toward a General Theory of Contractual Obligation, 69 VA. L. REV. 967, 971 n.11 (1983) (noting that contracting parties allocate risks to those who are best able to bear the risks).

Professors Goetz and Scott explain that parties are prevented from forming complete contingent contracts-allocating all the risks in the document-only by the costs of negotiating and actually writing the terms. As Professor Subha Narasimhan has adeptly summarized: "Under this view, while the contract is incomplete, the contract as supplemented with the underlying contract rules represents a complete allocation made by the parties." Subha Narasimhan, Of Expectations, Incomplete Contracting, and the Bargain Principle, 74 CAL. L. REv. 1123, 1129-30 n.24 (1986). Thus, although parties to a complete contingent contract may choose to assume certain risks, those risks are foreseeable and allocated by the parties in the agreement. See Charles J. Goetz \& Robert E. Scott, The Limits of Expanded Choice: An Analysis of the Interactions Between Express and Implied Contract Terms, 73 CAL. L. REv. 261, 267 \& n.10 (1985) (discussing contractual deficiencies arising from imperfect communication and definition).

14 For a definition of the "one drop of blood rule," see infra note 23. 
segregation is increasing rather than decreasing in a society in which racism is regarded as irrational and wrongheaded. In addition, I attempt to resolve yet another well-documented paradox. Because Blacks are disproportionately represented among the poor, they should be disproportionately represented in poor communities consonant with their proportion in that population. ${ }^{15}$ Moreover, because both poor whites and poor Blacks have limited choices in housing due to their impoverished state, one would expect them to live in the same communities. Quite the contrary, as Part III demonstrates, there is more, rather than less, segregation among the poor.

Looking at it from one perspective, in a world in which higher income means more choices, it is perhaps easier to explain why a wealthy community may be totally segregated, or all-white. For example, one could envision a scenario in which whites move out when Blacks move into the community. ${ }^{16}$ That option is more easily available if the whites have the financial assets to relocate easily.

More realistically, another factor leading to that all-white wealthy community may be the fact that no Blacks have the requisite income to purchase housing in that neighborhood. Hence, the market may work to preclude integration. Another, more insidious factor may be that the residents of the wealthy community, who have many choices about where to live, may freely choose to situate themselves in communities in which only other whites live. ${ }^{17}$ In a

${ }^{15}$ See, e.g., Michael F. Potter, Note, Racial Diversity in Residential Communities: Societal Housing Patterns and a Proposal for a "Racial Inclusionary Ordinance", 63 S. CAL. L. REV. 1151, 1169 (1990) ("If income were a primary factor [in producing segregated communities], racial diversity would be highest in lower income communities."). For further discussion of this issue, see infra notes $143-45$ and accompanying text.

${ }^{16}$ This is exactly what happens at lower income levels through the practice known as "blockbusting." Realtors used blockbusting methods "to open up neighborhoods to black entry and to reap profits during the transition." MASSEY \& DENTON, supra note 3, at 37. Massey and Denton explain the process as follows:

Blockbusting agents would select a promising area for racial turnover, most often an area adjacent to the ghetto that contained older housing, poorer families, aging households, and some apartment buildings. Agents would then quietly acquire a few homes or apartments in the area, and rent or sell them to carefully chosen black families. Given the intensity of black demands and the depths of white prejudice, the entry of a relatively small number of black settlers would quickly surpass the threshold of white tolerance and set off a round of racial turnover.

Id. at 37-38.

${ }^{17}$ For example, high-priced cooperative apartments, or "co-ops, "in New York City 
world in which the poor have fewer choices because of their necessitous economic situation, one would expect that the socioeconomic status of the poor, both white and black, would consign them to live in relatively integrated, "poor" communities in which the only defining characteristic of the inhabitants is poverty.

As Part III details, however, an examination of the data reveals that the poor are more likely to live in segregated communities than those who are economically advantaged. Indeed, it is my hypothesis that Blacks will encounter less discrimination and racism as they achieve higher degrees of economic status. ${ }^{18}$ In this context, money or socioeconomic status has an impact on the degree of segregation experienced by Blacks. Poverty, then, serves a dual role in the maintenance of Black segregated communities. First, poverty and all that it entails ${ }^{19}$ reinforces negative racial stereotypes of Blacks by whites and leads to efforts to exclude and separate. Second, the poverty experienced by whites causes them to value the only significant attribute they possess-the property right in their

are well-known for the selectivity that they apply in approving or rejecting prospective tenants. See JESSE DUKEMINIER \& JAMES E. KRIER, PROPERTY 934-35 (3d ed. 1993) (noting that "numerous prominent persons have been excluded from cooperative apartments," including ex-President Richard Nixon).

${ }^{18}$ See ThOMas Sowell, RaCE AND CulTuRE 106-07 (1994). Sowell believes that as groups become more acculturated into mainstream norms, they become more geographically or spatially integrated into society. His explanation for the existence of ghettos is premised on the post-World War II mass migration of southern rural Blacks into cities. His thesis fails to explain, however, why this group, which has populated the ghetto for 80 years, has not moved on to more affluent neighborhoods as did their Irish, Jewish, or other immigrant predecessors. For further discussion, see infra notes 25-26, 136-41 and accompanying text.

${ }^{19}$ Here I am referring to poor educational opportunities, crumbling infrastructure, poor housing, and little or no economic opportunities that inevitably lead to a rise in criminal behavior and drug use, along with the residents' increased reliance on public support such as Aid to Families with Dependent Children (AFDC), that all nicely dovetail with prevailing negative stereotypes of Blacks. For a further discussion of this phenomenon, see MASSEY \& DENTON, supra note 3, at 118-25 (contending that racial segregation concentrates poverty in minority neighborhoods). See also Douglas S. Massey, Getting Away with Murder: Segregation and Violent Crime in America, $143 \mathrm{U}$. PA. L. REV. 1203, 1210-17 (1995) (linking high rates of Black crime to high levels of Black poverty and high levels of segregation); Michael H. Schill \& Susan M. Wachter, The Spatial Bias of Federal Housing Law and Policy: Concentrated Poverty in Urban America, 143 U. PA. L. REV. 1285, 1286-90 (1995) (describing the increase in concentrated poverty in U.S. cities over the past two decades and the resultant problems); infra notes 65-67 and accompanying text (stating that poverty in the ghetto has created the underclass and the problems associated with the inner city); infra part III (discussing the impact of the property right in whiteness on the urban poor). 
whiteness-and leads them to go to great lengths to protect this valuable asset.

Part III concludes by focusing on the intersection of race and poverty from a different perspective, a perspective that is enriched by the insights provided by recent scholarship in Critical Race Theory. ${ }^{20}$ Part III demonstrates that the traditional analysis of the intersection of race and poverty and its impact on segregated residential housing is flawed and incomplete because it fails to properly take into account the "property" value that whites derive from maintaining their superior racial classification as whites. Much scholarship has recently been devoted to detailing the property or status value that whites obtain in maintaining a racial distinction between themselves and others. ${ }^{21}$

Concomitantly, what is missing in that scholarship is the role that residential segregation plays in maintaining the property or status value of superiority. Hence, Part III attempts to provide a piece that fits two different puzzles. First, I demonstrate that the value that whites derive in maintaining their whiteness is a primary factor leading to the residential segregation that is prevalent in society. Second and synergistically, that geographic separation from Blacks and others creates a property or status value in whiteness, especially among the lower socioeconomic classes.

Given that insight, Part IV turns to what can be done to reduce the residential segregation produced by racism, poverty, and the creation of a property right in whiteness. Yet another paradox is revealed that is explanatory of the law's failure to remediate housing discrimination. I contend that housing discrimination (and other forms of discrimination like employment discrimination) will not be

${ }^{20}$ Although it was once popular to attempt to define the parameters of Critical Race Theory by reference to the articles that are correctly characterized as representative of this genre of legal scholarship, see, e.g., Roy Brooks \& Mary Jo Newborn, Critical Race Theory and Classical-Liberal Civil Rights Scholarship: A Distinction Without a Difference?, 82 CAL. L. REv. 787, 787 n.3 (1994) (citing writings on Critical Race Theory); Peller, supra note 10, at 758 n.2 (defining Critical Race Theory), I choose not to do so because any such attempt is doomed to fail due to the overabundance of literature that may properly be characterized as Critical Race Theory. For a relatively recent summary of Critical Race Theory articles, see Richard Delgado \& Jean Stefancic, Critical Race Theory: An Annotated Bibliography 1993, A Year of Transition, 66 U. CoLO. L. REv. 159 (1995); Richard Delgado \& Jean Stefancic, Critical Race Theory: An Annotated Bibliography, 79 VA. L. REV. 461 (1993).

${ }^{21}$ See, e.g., Richard H. McAdams, Cooperation and Conflict: The Economics of Group Status Production and Race Discrimination, 108 HARV. L. REV. 1003, 1019-33 (1995) (discussing the individual preference for esteem and status within a group). For further discussion of this issue, see infra part III. 
eliminated as long as the goal, the attainment of a color-blind society in which race is irrelevant, is inconsistent with the manner in which race is treated by law and society. Antidiscrimination law in housing is modeled on a premise that race is and should be irrelevant (which, of course, is a laudable goal or ideal). Race, however, albeit socially constructed, ${ }^{22}$ continues to matter. The fact that race is socially constructed must be confronted because it reveals a much deeper problem. The problem, or inconsistency, that leads to the failure of antidiscrimination law in housing is the American legal system's incorporation of the recognition of race and the differentiation of individuals based on race. In Part IV, I contend that it is impossible to eradicate racial discrimination as long as the current racial typography is maintained in which white is differentiated from Black by the "one drop of blood rule." ${ }^{23}$

In a perfect world, race would be eliminated as a category pursuant to which individuals are segregated and classified. Because a perfect world does not exist, eliminating all racial classification from the law-for example, in the census-is unrealistic because it fails to recognize that race has mattered up to this point in time. ${ }^{24}$ Thus,

${ }^{22}$ On this I find myself in rare agreement with Professor Sowell:

Neither race nor related concepts can be used in any scientifically precise sense to refer to people inhabiting this planet today, after centuries of genetic intermixtures. The more generic term, race, will be used here in a loose sense to refer to a social phenomenon with a biological component, rather than make a dichotomy whose precision is illusory.

Whatever the biological reality, race as a social concept is a powerful force uniting and dividing people. Whether visible on the physical surface or simply felt in the emotional depths, race provides the cohesive groupings in which cultures have been concentrated, transmitted and carried around the world.

SOWELL, supra note 18, at 6; see also infra note 24.

${ }^{23}$ Gotanda, supra note 8 , at 24. Professor Gotanda describes the "one drop of blood rule" as follows:

American racial classifications follow two formal rules:

1) Rule of recognition: Any person whose Black-African ancestry is visible is Black.

2) Rule of descent: (a) Any person with a known trace of African ancestry is Black, notwithstanding that person's visual appearance; or, stated differently, (b) the offspring of a Black and a white is Black.

Id. (footnote omitted).

${ }^{24}$ Indeed, it is appropriate to note at this early stage that what I find puzzling, problematical, and ultimately paradoxical is that much of the data on residential housing segregation is premised on a category-race-that has no fixed, scientific meaning. To prove the segregation of neighborhoods, one must prove Blacks and 
instead of asking for the abolition of all racial categories or classifications, I propose a more modest step: destabilizing racial classifications in such a way that the property value in whiteness, and the characterization of Blacks as outsiders, is severely weakened, if not eliminated. This destabilization addresses housing discrimination from a different perspective. This perspective acknowledges that as long as there are stable categories of "white" on the one hand, and "Black" on the other, whites have an economic incentive to maintain their alleged racially superior status as white. To reduce that incentive, one must eliminate the artificial racial distinction between whites and Blacks. Integration will ensue when racial identification becomes fluid and contingent rather than fixed and definitive.

\section{AN EMPIRICAL AND Historical ANALYSIS OF SEgREgation IN THE RESIDENTIAL HOUSING MARKET}

In this Part, I begin by noting both the extent of residential segregation and the traditional rationales put forth to explain the continued and increasing amount of residential segregation in contemporary American society. These rationales are then analyzed and detailed to provide a baseline pursuant to which my thesis concerning the unique interaction or intersection of race and poverty can be measured and tested. Particular attention is paid to the twin causes of racism and poverty as causative factors for the construction and persistence of segregated ghettos. ${ }^{25}$ My thesis represents an attempt to build on, rather than refute, these conventional rationales and to demonstrate that they are incomplete

whites are distinct. If indistinct scientifically, genetically, or biologically, the distinctiveness provided by race must be socially constructed. See supra note 22 . If socially constructed, it can be deconstructed. That, in essence, represents the purpose of Part IV of this Article. I propose the method of deconstruction in Alex M. Johnson, Jr., Destabilizing Racial Categorizations Based on Lessons from Trademark Law (1995) (unpublished manuscript, on file with author). See also supra note 22 and accompanying text.

${ }^{25}$ For the purposes of this Article, I will follow Massey and Denton's use of the term "ghetto":

[A] ghetto is a set of neighborhoods exclusively inhabited by members of one group, within which virtually all members of that group live. By this definition, no ethnic or racial group in the history of the United States, except one, has ever experienced ghettoization, even briefly. For urban Blacks, the ghetto has been the paradigmatic residential configuration for at least eighty years.

MASSEY \& DENTON, supra note 3, at 18-19. 
because the manner in which racism and poverty interact is based on fixed and stable characterizations of what is white and, conversely, what is Black. Those characterizations play an important role in consigning Blacks uniquely to ghettos from which few can escape. ${ }^{26}$

\section{A. The Prevalence of Segregation}

It is beyond cavil that the vast majority of Blacks live in urban residential ghettos. The problem, as Massey and Denton demonstrate in their path-breaking work, is the perception that residential segregation, and the harms engendered thereby, were terminated with the passage of the Fair Housing Act of 1968. ${ }^{27}$ Thus, although race and related issues ${ }^{28}$ continue to command the attention of many of our best legal scholars ${ }^{29}$ and social scientists,

${ }^{26}$ As the previous footnote indicates, the ghetto has been the singular province of Blacks. In this context, then, the dissimilar experiences of other minorities and immigrant groups is quite instructive. Whereas many immigrants from Europe and Latin America experienced U.S. cities as "vehicles for integration, economic advancement, and ultimately, assimilation into American life," rural Blacks found that these same cities "became a trap" that ensured their "continued subordination." Id. at 18. The key question, of course, is why has the experience been unique for Blacks? The answer, I contend, has much to do with the legacy of slavery and the operation of the one drop of blood rule that precludes the assimilation of any members of this group into "white society," but does not preclude the assimilation of immigrant groups and other minorities (except perhaps Asian-Americans). In another article, I attempt to explain why Blacks have not been assimilated into American society, and I compare that failure to assimilate to the successful assimilation of other minority groups, especially Asian-Americans. See Johnson, supra note 24. For a discussion of the unique position in which Asian-Americans find themselves as the "model minority," see Pat K. Chew, Asian Americans: The "Reticent" Minority and Their Paradoxes, 36 WM. \& MARY L. REV. 1 (1994) (detailing the dissimilar experiences of Asian-Americans in American society and the paradoxes created by these experiences when their collective experience is compared to the myths and public perception of that racial group).

${ }^{27}$ See Chew, supra note 26, at 3-9.

${ }^{28}$ Related issues include affirmative action, see Daniel Farber, The Outmoded Debate over Affirmative Action, 82 CAL. L. REV. 893 (1994) (analyzing the affirmative action debate and focusing on the views expressed by critical race theorists); Alex $M$. Johnson, Jr., Defending the Use of جuotas in Affirmative Action: Attacking Racism in the Nineties, 1992 U. ILL. L. REv. 1043 (contending that the debate over the existence and merit of affirmative action programs has been improperly transmuted into a debate over the existence and merit of quotas), and the even more controversial issue of whether Blacks are genetically, intellectually inferior to whites. See CHARLES MURRAY \& RICHARD J. HERNNSTEIN, THE BELL CURVE (1994) (arguing that intelligence as measured by IQ scores is correlated, to some degree, with racial identification). For a more well-reasoned and lucid discussion of race, intelligence, and heredity, see SOWELL, supra note 18, at 156-85. Charles Murray's earlier contribution to race relations was presented in his book, LOSING GROUND: AMERICAN SOCIAL POLICY, 1950-1980 (1984) (arguing that welfare produces poverty among Blacks).

${ }^{29}$ See supra note 20 (citing recent legal scholarship on the issue of race).

${ }^{30}$ See, e.g., Life NOTES: PERSONAL. WRITINGS BY CONTEMPORARY BLACK WOMEN 
many have ignored the issues raised by the continued persistence of the ghetto and its impact on American society.

What needs to be recognized and popularly acknowledged, as it has been documented, is that the promise of racial integration of the Sixties and Seventies has given way to the failure of integration in the Eighties and Nineties. The advent of the Fair Housing Act, along with other civil rights acts, ${ }^{31}$ as well as the broadening use of affirmative action to integrate colleges and universities ${ }^{32}$ and the workplace, ${ }^{33}$ all seemed to portend significant changes in American race relations in the late Sixties and the Seventies. In addition, as Blacks as well as whites moved to suburbs, and as the migration of Blacks to northern urban cities reversed itself, demographic patterns seemed to support racial integration. ${ }^{34}$ Lastly, economic conditions seemed to favor residential integration due to the fact that in the late Sixties and early Seventies Black income levels were rising, culminating in the lowest rate of Black poverty in United States history in $1973 .{ }^{35}$

By 1980 , however, the dream of integration had given way to the reality of increased segregation of our major urban cities and the problems associated with such ghettos:

[I]n contrast to the steady improvement in black socioeconomic status through 1973, the decade ended in record unemployment, inflation, falling wages, increasing income inequality, and rising rates of black poverty. Not only did the ghetto fail to disappear; in many ways its problems multiplied. As segregation persisted, black isolation deepened, and the social and economic problems

(Patricia Bell-Scott ed., 1994); LuRE AND LOATHING, supra note 8; THOMAS SOWELL, The EConomics and Politics of Race (1983); Studs Terkel, Race: How Blacks and Whites Think and Feel About THe American Obsession (1992); CoRnel WEST, RACE MATTERS (1993).

s1 See, e.g., Voting Rights Act of 1965, Pub. L. No. 89-110, 79 Stat. 445 (codified as amended at 42 U.S.C. $\$ \$ 1971,1973$ to 1973 bb-1 (1988 \& Supp. V 1993)); Civil Rights Act of 1964, tit. II, Pub. L. No. 88-352, 78 Stat. 243 (codified as amended at 42 U.S.C. $\$ 2000$ a (1988 \& Supp. V 1993)); Civil Rights Act of 1964, tit. VII, Pub. L. No. 88-352, 78 Stat. 253 (codified as amended in scattered sections of 42 U.S.C. (1988 \& Supp. V 1993)).

32 See, e.g., Regents of Univ. of Calif. v. Bakke, 438 U.S. 265 (1978) (defining the constitutional boundaries of affirmative action programs).

${ }^{\text {ss }}$ See, e.g., United Steelworkers of Am. v. Weber, 443 U.S. 193 (1979) (discussing affirmative action in the workplace under Title VII).

34 MASSEY \& DENTON, supra note 3, at 60.

${ }^{35}$ Id. at $60-61$. 
that had long plagued African American communities worsened. During the 1970 s, the ghetto gave birth to the underclass. ${ }^{36}$

An examination of housing statistics reveals that segregation is still near pre-Brown levels, and little progress toward integration has been made. ${ }^{37}$ In almost every major northern metropolitan area, ${ }^{38}$ whites live in neighborhoods that are almost exclusively white, and Blacks live in predominantly, almost overwhelmingly, Black neighborhoods. ${ }^{39}$ In some cities, the segregation is as complete as it was when it was legislated and enforced judicially; " $[t]$ he parks, schools, city services, and churches for black neighborhoods attract few, if any, white patrons."

${ }^{36} I d$. at 61 (endnote omitted).

${ }^{37}$ On a scale of zero to 100 , with 100 representing total segregation, U.S. housing in 1980 rated an 80 for the 16 metropolitan areas with the largest Black populations, representing only slight improvement from previous decades. See A CoMMON DESTINY: BLACKS AND AMERICAN SOCIETY 27 (Gerald D. Jaynes \& Robin M. Williams, Jr. eds., 1989) [hereinafter A COMMON DESTINY] (noting a drop of an average of six rating points compared to the 1970 segregation survey); see also Sharman Stein, Study Challenges Notions of "Black Flight", CHI. TRIB., Mar. 29, 1990, at 1, 21 ("Although discrimination against blacks in the labor force, and in public life generally, has fallen markedly since the $1960 \mathrm{~s}$, housing is one area where discrimination and segregation have persisted' . . . " (quoting Douglas Massey, Professor of Sociology, University of Pennsylvania)).

${ }^{38}$ MASSEY \& DENTON, supra note 3, at 63-65 (stating that, as a result of "distinctive Southern traits," segregation levels are lower in Southern urban areas when compared to Northern urban areas).

${ }^{39}$ In 15 of the 29 metropolitan areas with the largest Black populations in 1980, whites lived in neighborhoods that were $90 \%$ or more white. See A COMMON DESTINY, supra note 37, at 90. Blacks in Chicago, Detroit, and Cleveland lived in neighborhoods that were at least $80 \%$ Black. See id. In their study on the extent of segregation in residential areas, Massey and Denton determined that

roughly one-quarter of the American black population lives in an urban environment that is hypersegregated. . . . Residents of such an environment would be very unlikely to come into regular contact with a member of Anglo society, except through participation in the labor force, an option that is denied to the quarter of central-city blacks who are under-or unemployed.

Massey \& Denton, supra note 6, at 382. Massey and Denton further observed that only $2 \%$ of metropolitan Blacks live in a residential pattern that may be considered "integrated." Id.

${ }^{10}$ See, e.g., Village of Arlington Heights v. Metropolitan Hous. Dev. Corp., 429 U.S. 252, 270-71 (1977) (prohibiting racially motivated zoning decisions that result in residential discrimination, but failing to find racial animus in the case at hand); Shelley v. Kraemer, 334 U.S. 1, 18-23 (1948) (holding unanimously that the Equal Protection Clause forbids courts from enforcing racially restrictive covenants).

${ }^{41}$ A COMmon DESTINY, supra note 37, at 91; see also Massey \& Denton, supra note 6 , at 389 ("Not only are blacks in our largest cities disproportionately likely to share tracts with other blacks, they are very unlikely to share a tract with any whites at all."). 


\section{B. The Causes of Segregation}

Four causes are often given to explain both the existence of residential segregation and what has caused that segregation to increase rather than dissipate following the passage of the Fair Housing Act of 1968. ${ }^{42}$ First, racism no doubt continues to exist and to cause whites to resist living with or around Blacks in integrated neighborhoods. ${ }^{43}$ Opinion polls mask the racism that is prevalent in American society because they continue to show that whites, as well as Blacks, adopt the principles of housing access and equal treatment in race relations in their rhetoric but not in their practices. ${ }^{44}$ One study concluded that "[i]n practice, many whites refuse or are reluctant to participate," embrace, or operate on these principles if the result is "close, frequent, or prolonged social contact" with minorities, such as living next door to them. ${ }^{45}$ Basically, "the prevalent white attitude is 'Yeah, I'm for integration, but not in my neighborhood."

${ }^{12}$ Some have attributed the failure of the Fair Housing Act to remediate segregation to a systemic and fundamental defect:

Although a comprehensive open housing bill finally passed Congress under unusual circumstances in 1968, it was stripped of its enforcement provisions as its price of enactment, yielding a Fair Housing Act that was structurally flawed and all but doomed to fail. ...

..

As long as the Fair Housing Act is enforced individually rather than systematically, it is unlikely to be effective in overcoming the structural arrangements that support segregation and sustain the ghetto. Until the government throws its considerable institutional weight behind efforts to dismantle the ghetto, racial segregation will persist.

MASSEY \& DENTON, supra note 3, at 14-15.

${ }^{43}$ Although it is indeed plausible that there are numerous Blacks who, if given a meaningful choice, would choose not to live with whites, for the purpose of this Article I make what I hope is a reasonable assumption that given the paucity of services and the crumbling infrastructure of the ghetto, most Blacks would prefer to live in integrated communities with whites, if only to obtain the higher level of services associated with such neighborhoods. A more difficult question is presented if it is assumed that similar services can be provided to ghetto dwellers. In that situation, real questions arise concerning whether integration is a particularly viable strategy for Blacks. For further discussion of this point, see supra note 10 and accompanying text (discussing theories about whether Blacks would integrate if given the choice).

14 See Johnson, supra note 28, at 1049.

15 A COMMON DESTINY, supra note 37 , at 11.

${ }^{46}$ Walter Shapiro, Unfinished Business, TIME, Aug. 7, 1989, at 12, 15. This is best characterized as the current equivalent of the oft-expressed sentiment of the Eighties, "Some of my best friends are Blacks, but I wouldn't want my daughter to marry one," that is articulated to prove how liberal the speaker is when it comes to race relations. 
Moreover, even though this society has adopted, in principle, an antidiscrimination norm in which race and other immutable characteristics are deemed irrelevant to entitlement distributions, it is beyond peradventure that race and racism, especially as it applies to Blacks when compared to other racial and ethnic groups, continue to matter and cause detriment to Blacks when compared to similarly situated whites and, to a lesser extent, other minorities. In other words, Blacks continue to be victimized by discrimination $^{47}$ in American society in general and in the housing market in particular. $^{48}$

More importantly for the purposes herein is the proof that there is a significant link between discrimination, racism, or prejudice and the resulting segregation. ${ }^{49}$ That discrimination leads to segregation might seem to a casual observer obvious and in little need of defense or justification. What must not be overlooked nor ignored, however, is the cyclical or synergistic effect that discrimination has on the production of an underclass that is spatially limited to urban ghettos. ${ }^{50}$

${ }^{17}$ Professor Cass R. Sunstein has aptly and accurately described the term "discrimination" as "protean." Cass R. Sunstein, Why Markets Don't Stop Discrimination, Soc. PHIL. \& POL'Y, Spring 1991, at 22, 22 n.1. For working purposes, I provide Professor Sunstein's definition of discrimination, with which I agree:

Discrimination should, I suggest, be understood to include any decision that treats an otherwise similarly qualificd black, woman, or handicapped person less favorably than a white, male, or able-bodied person, whether the reason for the decision lies in malice, taste, selective empathy and indifference, economic self-interest, or rational stereotyping. This understanding of discrimination picks up not merely covert unequal treatment, but also requirements that are neutral "on their face" but that would not have been adopted if the burdened and benefitted groups had been reversed. It does not pick up measures merely having discriminatory effects unless those effects are, in the sense indicated, tied up with racial, sexual, or other bias.

Id. at 34 (footnote omitted).

${ }^{48}$ Massey and Denton come to a similar conclusion. See MASSEY \& DENTON, supra note 3 , at 109 (stating that "discrimination against blacks is widespread and continues at very high levels in urban housing markets").

${ }^{49}$ See, e.g., George C. Galster, More Than Skin Deep: The Effect of Housing Discrimination on the Extent and Paltern of Racial Residential Segregation in the United States, in Housinc DeSEgregation AND FEderal Policy 119, 129-31 John M. Goering ed., 1986) (confirming, through data gathered from a 1977 survey by the U.S. Department of Housing and Urban Development, an empirical link between discrimination and segregation). But see MASSEY \& DENTON, supra note 3, at 109 ("The persistence of prejudice, discrimination, and segregation in American cities strongly suggests a possible causal connection, but a mere coincidence of trends does not necessarily link racist attitudes and behaviors to segregation.").

${ }^{50}$ Massey and Denton also note this aspect of Galster's findings: 
Although causally linked to racism, the outward flight of whites to suburbia-leaving, as one songwriter described, a "chocolate city" surrounded by "vanilla suburbs" residential segregation patterns in an era in which overt racism has diminished and lost favor. The white exodus to outlying areas causes further depredations in the inner city and leads to an inadequate tax base for school funding and other social programs and initiatives. ${ }^{2}$

As cities have maintained their place as economic and financial centers, one can only guess what urban neighborhoods might look like in the absence of suburbs. The existence of suburbs has allowed cities to maintain their economic promise and vitality while at the same time creating and maintaining the deplorable segregated conditions that detrimentally impact Blacks. Not so coincidentally, the creation and subsidization ${ }^{53}$ of suburbs not only allow for segregated neighborhoods, but also provide a stable white work force or employee base that makes those who are geographically proximate to the jobs-Blacks in the inner city-largely superfluous.

The third factor that has led to increased segregation is the existence of government and private lender policies that discriminate against Blacks in the residential housing market in such a way as to restrict Blacks' choice of housing locales. It is fairly well documented that the construction of the urban ghetto as we know it was in place prior to World War II: a confluence of factors coalesced shortly after the war and continued through the Seventies,

[Galster] also discovered that segregation itself has important feedback effects on socioeconomic status. Not only does discrimination lead to segregation, but segregation, by restricting economic opportunities for blacks, produces interracial economic disparities that incite further discrimination and more segregation.

MASSEY \& DENTON, supra note 3, at 109 (endnote omitted).

${ }^{51}$ See id. at 61 (citing MALBIX/RICKS MustC, Chocolate City (Casablanca Records 1976)).

52 On the differential school funding rates for white and Black students, see JONATHAN KOZOL, SAVAGE INEQUALITIES 119-24 (1991).

53 The use of tax dollars to build freeways and highways is appropriately viewed as a subsidy for whites who need easy ingress and egress to and from their urban work place. "In making this transition from urban to suburban life, middle-class whites demanded and got massive federal investments in highway construction that permitted rapid movement to and from central cities by car." MASSEY \& DENTON, supra note 3 , at 44 . It is interesting to speculate what the inner cities or ghettos would look like if the same degree of resources were poured into the infrastructure of these communities. 
solidifying the presence and expansion of the Black ghetto. ${ }^{54}$ Moreover, it is neither original nor insightful to note that it was discriminatory action on the part of realtors and other private actors in the real estate industry that was a major causative factor in the birth and maintenance of the ghetto. ${ }^{55}$

Similarly, it is fairly well-known and documented that what is true today with respect to the discriminatory animus and patterns of private residential mortgage lenders ${ }^{56}$ was also true historically and had a significant impact on the construction of the ghetto. ${ }^{57}$ What is not as well-known and in need of publication is the government's role, through its agencies, in actively constructing the ghetto and the responsibility it bears for the current segregation therein. Indeed, although "redlining" is decried as an insidious tool of private bankers to limit lending to certain (minority) neighborhoods, the genesis of redlining rests with the federal government and can be traced, until very recently, to government edicts:

Beginning in the 1930s, the federal government launched a series of programs designed to ... make home ownership widely available to the American public. The Home Owners' Loan Corporation (HOLC) was the first of these programs, and it served as a model for later efforts. ...

Unfortunately for blacks, the HOLC also initiated and institutionalized the practice of "redlining." This discriminatory

5t See id. at 42-57.

${ }^{55}$ Massey and Denton trace the discriminatory policies of realtors over the past 40 years:

[A] comprehensive study of real estate policies in the $1950 \mathrm{~s} \ldots$ revealed a pervasive pattern of discrimination against blacks in most American cities. In [the] survey of real estate agents in Chicago, [it was] found that $80 \%$ of realtors refused to sell blacks property in white neighborhoods, and $68 \%$ refused to rent them such property. Moreover, among those agents who did sell or rent to blacks, half said they would do so only under restrictive conditions, such as when a significant number of blacks had already entered the area. Another survey of Chicago's real estate agents ... in the mid1960 s found that only $29 \%$ of agents were willing to rent to blacks unconditionally (regardless of local market conditions or racial composition), and half of these open-minded agents were black.

$I d$. at 50 (endnotes omitted).

${ }^{56}$ See infra notes 58-63 and accompanying text (tracing redlining by private banks to federal government policies beginning in the 1930s).

${ }^{57}$ See MASSEY \& DENTON, supia note 3, at 50-51 ("Among realtors offering information on the issue, $62 \%$ felt that few or very few banks were willing to make loans to blacks, and half of the agents confirmed that banks would not make loans to areas that were black, turning black, or threatened with the possibility of black entry."). 
practice grew out of a ratings system HOLC developed to evaluate the risks associated with loans made to specific urban neighborhoods. Four categories of neighborhood quality were established, and lowest was coded with the color red; it and the next-lowest category virtually never received HOLC loans. ${ }^{58}$

What is almost unknown and also worthy of a lengthy quotation is the extent to which both the Federal Housing Administration (FHA) and Veterans Administration (VA) programs that spurred the development of single-family home ownership were skewed in favor of encouraging the growth of white suburbia and against maintaining the inner city, which was and is largely populated by Blacks:

[T] he marriage of FHA financing and new construction techniques made it cheaper to buy new suburban homes than to rent comparable older dwellings in the central city. As a result, the FHA and VA contributed significantly to the decline of the inner city by encouraging the selective out-migration of middle-class whites to the suburbs.

... FHA practices and regulations ... favored the construction of single-family homes but discouraged the building of multifamily units. . . . But the most important factor encouraging white suburbanization and reinforcing the segregation of blacks was the FHA requirement for an "unbiased," professional appraisal of insured properties, which naturally included a rating of the neighborhood.

... In evaluating neighborhoods, the agency followed the HOLC's earlier lead in racial matters; it too manifested an obsessive concern with the presence of what the 1939 FHA Underwriting Manual called "inharmonious racial or nationality groups." According to the manual, "if a neighborhood is to retain stability, it is necessary that properties shall continue to be occupied by the same social and racial classes. ${ }^{n 9}$

This historical exegesis would be largely irrelevant if it were solely historical. Unfortunately, the discrimination that led to the creation and maintenance of redlining continues to exist in more subtle, yet no less effective, forms. As Peter Swire has shown, prior to enactment of the Fair Housing Act, the government (through various agencies), the realtors, and the financial institutions associated with the housing industry set in motion and helped perpetuate the very racial discrimination that the Fair Housing Act later

${ }^{58} \mathrm{Id}$. at 51 (endnotes omitted).

${ }^{59}$ Id. at 53-54 (endnotes omitted). 
outlawed. $^{60}$ Moreover, the effects of that earlier period of overt discrimination continue to have serious repercussions for Blacks wishing to purchase homes outside the largely Black ghettos. ${ }^{61}$

As recent empirical studies show, the discriminatory lending patterns and practices detailed by academicians is fact, not fiction. In tests conducted by undercover agents employed by the U.S. Department of Housing and Urban Development and the Federal Reserve Board, “[m]ortgage applications of minorities were rejected up to three times more frequently than applications of whites, even if they had similar incomes. ${ }^{62}$ Further, minority couples were given less information about financing, were steered into different neighborhoods than whites, and were told houses had been rented or sold when they really had not. ${ }^{63}$

The fourth factor that has led to the creation and maintenance of segregation is poverty. This factor, however, is complicated because poverty is not only a cause of segregation, but also a product. Consequently, poverty is synergistic in the housing context, both producing segregation and intensifying its effects. Thus, with regard to poverty, there is an economic component, or causative factor, of segregation that must be addressed. ${ }^{64}$

${ }^{60}$ See Peter P. Swire, The Persistent Problem of Lending Discrimination: A Law and Economics Analysis, 73 TEX. L. REV. 787, 793-802 (1995).

${ }^{61}$ One commentator has pointed out the lingering reverberations from earlier housing and lending policies:

The continuing discrimination and redlining in both mortgage and consumer credit hinder the ability of Black people to buy and improve their homes and therefore block asset accumulation, stakeholding, and revitalization in Black communities. The ongoing consolidation of the banking industry has had and will continue to have a profound negative impact in low- and moderate-income communities and in non-White communities.

Anthony D. Taibi, Banking, Finance, and Community Economic Empowerment: Structural Economic Theory, Procedural Civil Rights, and Substantive Racial Justice, 107 HARV. L. REV. 1463, 1466 (1994) (citation omitted).

${ }^{62}$ Margaret L. Usdansky, Housing Act Fails to Eliminate Bias Against Minorities, USA TODAY, Nov. 11, 1991, at 2A; see also Joel G. Brenner \& Liz Spayd, A Pattern of Bias in Mortgage Loans, WASH. POST, June 6, 1993, at Al ("A racially biased system of home lending exists in the Washington area, with local banks and savings and loans providing mortgages to white neighborhoods at twice the rate they do to comparable black ones . . . ."); H. Jane Lehman, Study: Race Factor in Loan Rejections, WASH. POST, Oct. 24, 1992, at F1 ("[D]ata collected under the Home Mortgage Disclosure Act . . . showed a loan rejection rate 170 percent greater for blacks and other minorities compared with that for whites.").

${ }^{63}$ See Usdansky, supra note 62 , at $2 \mathrm{~A}$.

${ }^{64}$ See MASSEY \& DENTON, supra note 3, at 84 (" $30 \%-70 \%$ of racial segregation is ... [allegedly related] to economic factors, which, together with urban structure and neighborhood preferences, 'bear much of the explanatory weight for present 
Poverty in ghetto neighborhoods created the underclass ${ }^{65}$ and the conditions of inner-city life with which we are all too familiar-crime and its related drug use, violence, undereducation, ${ }^{66}$ early pregnancy, welfare, and dependency. ${ }^{67}$ Similarly, discrimination and prejudice, combined with poverty, keep middle-class Blacks from leaving the ghettos. Such an escape would allow these families the opportunity to break the cycle of oppression generated by poverty conditions. ${ }^{68}$ Middle-class families experience difficulties moving out "because property values have declined and there are few buyers for their homes. ${ }^{n 9}$ If buyers are found, Blacks must then face discriminatory realtors and lenders, as well as the prospect that few middle-class neighborhoods will welcome them. ${ }^{70}$

Moreover, as Part III below details, a simultaneous analysis of race and poverty demonstrates that much of the discrimination against Blacks can be attributed to the fact that there is a property right in "whiteness" that poor whites maintain and protect through

residential patterns." (citation omitted)).

${ }^{65}$ Massey and Denton define the "urban underclass" as a coalescence of the images of "poor minority families mired in an endless cycle of unemployment, unwed childbearing, illiteracy, and dependency," who, in the eyes of white society, "were unlikely to exit poverty and become self-sufficient". Id. at 4-5 (citing MiCHAEL B. KATZ, THE UNDESERVING POOR: FROM THE WAR ON POVERTY TO THE WAR ON WELFARE 185-235 (1989)).

${ }^{66}$ Differences in socioeconomic status, when combined with residential separation, produce large disparities between whites and Blacks with regard to educational status. Black dropout rates are much higher than those of whites; Black performance on standardized achievement tests remains much lower than that of whites; and the percentage of Blacks attending and completing college is lower than that of whites and continues to decline. See A COMMON DESTINY, supra note 37, at 332-52 (analyzing the trends in Black educational attainment in, among other areas, high school, college, and standardized testing).

${ }^{67}$ See Massey \& Denton, supra note 6, at 389 ("Our results suggest that the extremity of black residential segregation and its unique multidimensional character may help explain the growing social and economic gap between the black underclass and the rest of American society.").

${ }^{68}$ For many ethnic groups, breaking the cycle of oppression and improving socioeconomic mobility can be thought of as

a cumulative process whereby economic advancement . . . is translated into residential progress (a higher-status neighborhood with better schools, peer influences and social contacts), which in turn leads to additional socioeconomic gains (children receive better educations and get better jobs). This avenue for cumulative socioeconomic advancement is largely closed to blacks because of racial barriers to residential mobility.

Douglas S. Massey, Racial Segregation Itself Remains a Corrosive Force: Blacks Held Back by Isolation Within Cities, L.A. TIMES, Aug. 13, 1989, at V5.

${ }^{69}$ Stein, supra note 37 , at 21.

${ }^{70}$ See supra notes $43-48,55-63$ and accompanying text. 
the enforcement of residential segregation. ${ }^{71}$ In addition, this property right differentially affects poor Blacks and precludes their integration to a greater extent than it does wealthier Blacks. ${ }^{72}$

Before commencing a meaningful discussion of the intersection of race and poverty and the resulting creation of whiteness as a property right, attention must be paid to the failure of traditional approaches to eliminate discrimination. ${ }^{73}$ These approaches, I will argue in Parts III and IV, failed because they inadequately internalized both the power of whiteness as a property interest or right (upon which entitlements are based) and the stable classifications of race (upon which the property interest or right is based).

Before exploring these theories and proposing a new legal regime in which the stable classifications of race can be deconstructed, I turn in Part II to an examination of the two traditional models for the elimination of residential housing segregation and an analysis of the defects of these approaches.

\section{Traditional Approaches to the Elimination OF DISCRIMINATION}

Well-intentioned advocates of social reform propose two diametrically opposed models to reduce and eliminate racial discrimination in housing, as well as in employment. The first, and less controversial, model is based on the notion that the law can intervene in otherwise private arrangements or contracts to eliminate or reduce social activity that may be personally neutral or even beneficial, but socially harmful (the "interventionist" model). Statutes such as Title II of the Civil Rights Act of $1964,{ }^{74}$ the Fair Housing Act of

${ }^{71}$ See infra part III.

${ }^{72}$ I contend that wealthier Blacks are not viewed as "authentically" Black by whites, in that wealthier Blacks do not fit the stereotypical images of poor, urban Blacks. As a result, wealthier Blacks are welcomed into all-white communities because they are less threatening than poor Blacks. See infra text following note 99.

${ }^{73} \mathrm{I}$ will return to this issue in Part IV, where I take the insights provided by Parts II and III, wed them to the traditional interventionist approach adopted in antidiscrimination legislation, and argue for the destabilization of racial categories. See infra part IV.

${ }^{74}$ Civil Rights Act of 1964, tit. II, 42 U.S.C. $\$ \S 2000$ a to $2000 \mathrm{a}-6$ (1988 \& Supp. V 1993). Title II of the Civil Rights Act of 1964 provides: "All persons shall be entitled to the full and equal enjoyment of the goods, services, facilities, privileges, advantages, and accommodations of any place of public accommodation, as defined in this section, without discrimination or segregation on the ground of race, color, religion, or national origin." 42 U.S.C. $\$ 2000$ a(a). The Civil Rights Act of 1964 defines public accommodations to include, inter alia, inns, hotels, motels, restaurants, 
$1968,{ }^{75}$ and Title VII of the Civil Rights Act of $1964^{76}$ epitomize this first model.

The more recent, and more controversial, model advocated to eliminate harmful or unwarranted discrimination is premised on an economic argument that the efficient operation of the market, free of governmental intervention or regulation, will inevitably lead to the eradication of discrimination because such discrimination is inefficient (the "market" model). ${ }^{77}$ In the context of this paper the relevant market would be defined as the residential housing market.

and movie theaters. See $\S 2000 \mathrm{a}(\mathrm{b})$ (defining public accommodations as public establishments that either affect commerce through their operations or are supported in their discrimination or segregation by state action).

${ }^{75}$ Fair Housing Act of 1968, 42 U.S.C. $\$ \S 3601-3631$ (1988 \& Supp. V 1993). The Fair Housing Act makes it "the policy of the United States to provide, within constitutional limitations, for fair housing throughout the United States." 42 U.S.C. $\S 3601$.

${ }^{76}$ Civil Rights Act of 1964, tit. VII, Pub. L. No. 88-352, 78 Stat. 253 (codified as amended in scattered sections of 42 U.S.C.). Title VII of the Civil Rights Act of 1964 provides:

It shall be an unlawful employment practice for an employer-

(1) to fail or refuse to hire or to discharge any individual, or otherwise to discriminate against any individual with respect to his compensation, terms, conditions, or privileges of employment, because of such individual's race, color, religion, sex, or national origin ....

42 U.S.C. \$ 2000e-2(a); see also MICHAEL I. SOVERN, LEGAL RESTRAINTS ON RACIAL DISCRIMINATION IN EMPLOYMENT 3-8 (1966) (discussing the problem of racial discrimination in employment that precipitated the adoption of Title VII).

7 As with most economic theories, the leading proponent of this thesis is Judge Richard A. Posner, who, drawing upon the pioneering work of Gary Becker, states:

Although discrimination is consistent with competition, ... there are economic forces at work in competitive markets that tend to minimize discrimination. In a market of many sellers the intensity of the prejudice against blacks will vary. Some sellers will have only a mild prejudice against them. These sellers will not forgo as many advantageous transactions with blacks as their more prejudiced competitors (unless the law interferes). Their costs will therefore be lower, and this will enable them to increase their share of the market. The least prejudiced sellers will come to dominate the market in much the same way as people who are least afraid of heights come to dominate occupations that require working at heights: They demand a smaller premium. This is not to say that discrimination will disappear. Discrimination based on taste-an unreasoned aversion to members of another race-will, if the above analysis is correct, disappear eventually from competitive markets. But efficient discrimination . . . will not, for efficient discrimination is the optimal strategy for any costminimizing firm, whether or not its owners or managers have any taste for discrimination.

RICHARD A. POSNER, ECONOMIC ANALYSIS OF LAW 652 (4th ed. 1992) (footnote omitted) (emphasis added); see also GARY S. BECKER, THE ECONOMICS OF DISCRIMINATION 122-25 (1957) (describing the concept of "taste" in regard to discrimination). 
Each model has its supporters and detractors, and it is fair to state that each model has established a body of voluminous scholarship whose full exegesis is beyond the scope of this Article. Nevertheless, each model can be criticized for its minimization of the function of race and racism in this society. Each model fails to internalize and address both the degree to which racial distinctions have become reified in this society and the steps that must be taken to reduce racism and discrimination in a world in which perceived differences between whites and Blacks are actualized.

The extent to which the market model imperfectly internalizes the reified racial distinctions in contemporary society, and the exposition of its weakness as a vehicle to eradicate discrimination in society at large or housing in particular, has already been explored by others. ${ }^{78} \mathrm{~A}$ brief review, focusing heavily upon the work of Professor Cass Sunstein, ${ }^{79}$ is warranted, however, if only to expose the symmetrical weakness of the interventionist model.

\section{A. Third-Party Effects}

One major flaw in the market model is that it fails to take into account the extent to which discriminating third parties are in a position to impose sanctions against those who wish to break rank and engage in nondiscriminatory behavior in order to operate efficiently. ${ }^{80}$ In the housing context, the market model presupposes that a landlord or a seller will have an economic incentive to sell to the highest bidder. ${ }^{81}$ If Blacks value living in an integrated

${ }^{78}$ See, e.g., John J. Donohue III \& James J. Heckman, Re-Evaluating Federal Civil Rights Policy, 79 GEO. L.J. 1713, 1728-29 (1991) (discussing extralegal social norms and sanctions that are used to perpetuate racial discrimination); McAdams, supra note 21 , at 60 (contending that rational behavior leads members of one racial group to seek to raise the relative status of their own group by lowering the status of other groups); Richard H. McAdams, Relative Preferences, 102 YALE L.J. 1, 44-48 (1992) (arguing that traditional economic analysis fails to internalize the concept of relative preferences, under which individuals measure wealth and utility compared to others).

${ }^{79}$ See, e.g., Cass R. Sunstein, Legal Interference with Private Preferences, 53 U. CHI. L. REV. 1129 (1986) (evaluating grounds for rejecting private preferences, as expressed in markets, as a basis for social choice); Sunstein, supra note 47 (arguing that in many settings markets will fail to stop discrimination).

${ }^{80}$ See Sunstein, supra note 47 , at 25 (contending that "third parties are frequently in a position to impose financial punishments on non-discriminatory employers").

${ }^{81}$ As Judge Posner states:

Economic analysis helps explain the variance in compliance with antidiscrimination laws. If the interracial associations brought about by such a law are slight, the cost of association even to prejudiced people will be low and they will not be willing to incur heavy costs in the form of punishment 
neighborhood more highly than like-minded whites (as they should if they live in segregated locales), they should be willing to pay a premium for integrated housing. As the high bidders, Blacks will supposedly move into the neighborhood until the state of integration establishes an equilibrium price at which whites and Blacks value entry into the neighborhood equally.

In the housing context, as in the typically modeled employment context in which the neutral employer must cede to her employees' taste for discrimination and act discriminatorily even though it is contrary to the employer's preference, ${ }^{82}$ third-party effects create discrimination. Although the interactions in the rental housing market duplicate the relational nature of interactions in the employment context, ${ }^{83}$ it is difficult to see how such third-party effects would work in the sale of one's residence-a one-shot, contingent transaction in which no continuing interaction takes place between vendor and vendee following completion of the transaction.

Although the sale of a residence seems to be immune from third-party pressure to discriminate, this pressure (and the pressure to operate supposedly against one's economic interest) is present when two related factors are taken into account: first, the value of whiteness as a property right, and second, the reexamination of this one-shot, contingent transaction to expose its "relational" characteristics that create an incentive to discriminate. ${ }^{84}$

for, or legal expenses of, resisting compliance in order to indulge their taste. It is not surprising that there has been general compliance with laws forbidding people to refuse on racial grounds to sell real estate, although few resources have been allocated to enforcing these laws. Unless the seller plans to stay in the neighborhood, his association with a black purchaser is limited to negotiating the sale (and a broker does that anyway). Most housing-discrimination cases, therefore, involve rentals rather than sales.

POSNER, supra note 77, at 658 (emphasis added). For a contrary view, see infra text accompanying note 86 (explaining how white sellers in a one-shot residential sale may still have an incentive to discriminate).

${ }^{82}$ See, e.g., Sunstein, supra note 47, at 25 (noting that "reliance on competitive pressures will force employers to behave in a discriminatory manner if they wish to survive").

${ }^{83}$ Interactions in the employment context are relational in that they involve one centralized decision-maker, the employer, in a relationship with a group of individuals, the employees, who must interact with each other in a cooperative manner to facilitate the group's interest, as well as the employer's interest. Expressed in terms of the rental housing market, the employer (landlord) has an ownership interest in an underlying asset (the dwelling units) that produces rents through the work of employees (tenants) who, in order to optimize profits, operate (live) in a cooperative manner.

\& For a definition of relational contracts, see supra note 13 . For further 
Turning to this first factor, assume that whiteness, including one's identification as a white person adhering to the collective norm that promotes whiteness as a property right, is internalized as a positive value by the white seller. Presume further that whites favor the preservation of all-white communities irrespective of the location of their own personal residence. This assumption can explain why white sellers (and, more obviously, white landlords) refuse to sell or rent to Blacks, even if the white seller does not lose the positive or associational attributes of being white when she sells her home to a Black and moves to another predominantly or exclusively white neighborhood.

An easy way to explain why whites refuse to sell to Blacks is to state that sellers have an incentive to discriminate against Blacks because of the simple and ultimately wrong-headed assumption that white sellers adhere to discriminatory norms because of what I will cavalierly characterize as the "Golden Rule" thesis. According to this thesis, whites don't sell to Blacks because they act on an internalized norm that they would not want their neighbors to sell to Blacks, and therefore they, in good conscience, cannot do so either. The Golden Rule thesis ignores, however, the power of greed and the market and thus must be rejected. ${ }^{85}$

The second and better explanation for why whites discriminate when selling their homes is that even though the transaction is aptly characterized as a one-shot, contingent transaction, it is not necessarily true that the players are involved in a thick market of buyers and sellers in which the interactions are random and anonymous. By selling her home, a seller of real estate may terminate her relationship with a piece of property; that does not mean, however, that the seller has terminated her relationship with the other owners in the neighborhood, even if it is assumed that the seller is moving out of the neighborhood. The friendships and relationships that the selling vendor developed while living in the soon-to-be-transferred residence represent the key to the puzzle in this context. The cost of losing those relationships, which may involve friendships between other family members (one's children

discussion of the relational nature of the real estate market, see infra notes 86-92.

${ }^{85}$ A variant of the Golden Rule Thesis is discussed below when it is argued that intragroup cooperation produces valuable group status that motivates the seller to sell only to other whites. See infra notes $92-93$ and accompanying text. This is not analogous to the Golden Rule Thesis because the seller is motivated not by altruism, but by the attainment of an economic benefit in maintaining the value of the neighborhood. 
playing with the neighbor's children), is the sanction that third parties can impose on the allegedly "traitorous" white neighbor who sells her home to a Black..$^{86}$

Once that cost is taken into account, a sufficient explanation may be given for why sellers act contrary to their alleged economic interests by refusing to sell their homes to Blacks. Racial solidarity, the privileging and the protection of whiteness as a property right, is achieved and considered rational in a world in which whiteness is a prized solidifying factor. Thus, in addition to maintaining past relationships, racial solidarity may be used to forge new relationships. As a result, a white moving into a new neighborhood may have an incentive to prove to prospective associates, friends, and neighbors ${ }^{87}$ that she is bonded to and is an upstanding member of the white community by demonstrating that the ties to her old community have been maintained and honored.

Richard McAdams has written about the pervasiveness and power of what he characterizes as negative relative preferences-that is "preferences for approaching or surpassing the consumption level of others." ${ }^{88}$ Professor McAdams argues that individuals care a great deal about achieving social status. ${ }^{89}$ In a later and related article, Professor McAdams expands his original thesis to argue that individuals seek "the esteem of others"; that is, people care about

${ }^{86}$ If my supposition is accurate, one would expect to see whites not selling to Blacks when they remain in close proximity to their old home or neighborhood. Similarly, one would expect to see fewer interracial transfers as the selling family and the relationships that the selling family creates and maintains in the older community or neighborhood increases. Indeed, I will go out on a limb and predict that perhaps the most frequent "blockbuster" who sells to an individual of a different race would be an estate seller. Given my theory, I would expect a trustee or executor of an estate of a deceased seller whose children have either long left the community or have no immediate family to be the most likely seller to Blacks. These estate sellers provide the perfect opportunity for the market to work without the external cost imposed by third-party sanctions.

${ }^{87}$ One other factor that could lead whites not to opt out and to protect their old neighborhood from encroachment or invasion by Blacks is the desire to maintain the reputational value of the neighborhood. Individuals can easily monitor behavior in this area by contacting those neighbors left behind to verify the bona fides of the new neighbor. Conversely, old, motivated neighbors can contact the "race traitor's" new neighbors to spread their poisonous venom regarding the sale of a house by their old neighbor to a Black. My assumption in this context is that it is virtually impossible to keep secret the location of one's new home.

${ }^{88}$ McAdams, supra note 78, at 9.

${ }^{89}$ See id. at 38-44 (demonstrating that status, or the respect that one commands from others, is an integral part of the human social condition). 
what others think about them, independent of any other end, including preserving one's relations within the community. ${ }^{90}$

In the context of residential housing and related transactions, one may view the purchase and sale of a home in a racially homogenous community as a cooperative endeavor in which the members of the community cooperate in order to keep "others" or "them" (Blacks) out of the community. The puzzle in economic terms is why individual owners, in this version of a prisoner's dilemma, ${ }^{91}$ do not defect when selling their homes. The answer has to do with group esteem, which parallels the property right in whiteness ${ }^{92}$ valued and maintained in all-white or segregated communities:

[S]ome individuals would cooperate in what is nominally a prisoner's dilemma solely to preserve the minimal esteem strangers (in that community) normally feel for one another. Esteem changes the payoffs of the game. Individuals add the "esteem rewards" and "esteem penalties" to the stated material payoffs, and choose accordingly. The combined payoff structure may favor cooperation even though the stated material payoffs, viewed in isolation, dictate defection. ${ }^{93}$

Viewing transactions in the residential real estate market as relational, rather than contingent, coupled with a recognition of the payoffs established by group identification and the production of group esteem, leads to a reconsideration of the traditional arguments attacking the rationality of racial discrimination and its degree of permanence. When these new factors are added to the equation, prefaced on a stable definition of race that tautologically reinforces the payoffs and esteem produced by group identification, the creation and prevalence of racial discrimination in housing remains quite plausible and rational. Hence, not only is discrimination statistically and economically rational (as the next section will discuss), it is also a necessary and intended byproduct of the stable racial classifications that cause relevant group identification.

${ }^{90}$ McAdams, supra note 21, at 25.

${ }^{9}$ The classic prisoner's dilemma is described as follows:

Two men, charged with a joint violation of law, are held separately by the police. Each is told that (1) if one confesses and the other does not, the former will be given a reward . . . and the latter will be fined . . . (2) if both confess, each will be fined... . At the same time, each has good reason to believe that (3) if neither confesses, both will go clear.

William Poundstone, Prisoner's Dilemma 117-18 (1992).

${ }^{92}$ For a discussion of the property right in whiteness, see infra part III.

${ }^{93}$ McAdams, supra note 21, at 24. 


\section{B. Statistical and Economically Rational Discrimination}

The traditional model of discrimination contains a second flaw that is equally applicable to renters and sellers of habitable dwellings, but may have a differential impact based on class component. The flaw that reduces the power of the market model to eradicate or reduce housing discrimination is produced because the very racial discrimination or animus that creates segregated neighborhoods may be in response to generalizations or stereotypes that have a rational basis. ${ }^{94}$ Unfortunately, that rational basis may be overbroad and discriminatory, leading to inefficiency. ${ }^{95}$

Indeed, as detailed previously, ${ }^{96}$ the pernicious effects of segregation create a crucible of poverty that leads to a permanent underclass whose low unemployment, undereducation, reliance on government benefits, relatively high addiction to drugs, and exposure to crime are proven facts. Race thus becomes a proxy, such that being a Black equates with being a poor tenant or poor neighbor. In a related context, Professor Sunstein has noted:

Along every indicator of social welfare-poverty, education, employment, vulnerability to private (or public) violence, participation in violent crime-blacks are less well-off than whites. And in light of those differences, it is fully possible that in certain settings, race- and sex-based generalizations are economically rational as proxies for relevant characteristics. Indeed, it is fully possible that race or sex is, in some contexts, every bit as accurate a signalling device as, say, test score, education, and previous employment. ${ }^{97}$

The problem with employing economically rational stereotypes is that doing so is contrary to this society's antidiscrimination norms and principles as embodied in the law; ${ }^{98}$ further, it requires innocent victims who do not conform to the stereotype to bear an impermissible burden. Lastly, although perhaps optimal from a short-term perspective, this type of behavior may be suboptimal in

94 See MASSEY \& DENTON, supra note 3, at 118 (noting that segregation and poverty synergistically create isolated communities in which "a variety of other deleterious conditions," such as joblessness, welfare dependency, crime, and single parenthood, become the norm).

${ }^{95}$ See Sunstein, supra note 47 , at 26 (suggesting that discriminatory behavior may be a response to generalizations that, although overbroad and invidious, provide an economically rational basis for employment decisions).

${ }^{96}$ See supra notes $65-67$ and accompanying text.

${ }^{97}$ Sunstein, supra note 47 , at 27.

${ }^{98}$ See id. at 28. 
terms of long-term societal goals, such as achieving a color-blind society in which race is not relevant. ${ }^{99}$

Moreover, it is this type of discrimination that reinforces class differences between upper-income Blacks and their poorer counterparts, who are unable to escape the conclusions generated by the stereotypes and generalizations. I hypothesize that it is easier for wealthier Blacks, simply as a function and byproduct of their wealth, to escape the stereotypes to which poor Blacks are subjected. Consequently, as one's income increases and socioeconomic status improves, the applicability of most of the other stereotypical attributes (education, crime, drug use, welfare, etc.) decreases. Wealth and its attainment become a "super-proxy" that negates the proxy created by one's status as a Black. To some extent, then, Black individuals are able to overcome their Blackness through economic attainment and success (as measured by white norms).

Hence, the Black urban poor are unable to escape from their necessitous circumstances because they lack the financial wherewithal to defeat the proxy associated with the color of their skin. Upper-income Blacks, however, have the means to diminish their racial identification with the disfavored group. If access to money and opportunity were equally provided, there would be little or no need for the interventionist model of discrimination because, to a large extent, the market model would work, albeit along class lines rather than race lines. That state of affairs would be normatively acceptable, assuming one accepts the current method of economic allocation in American society.

\section{The Effects of Discrimination on Human Capital}

Professor Sunstein has also demonstrated that the productivity of Blacks is "endogenous to, or a product of, discrimination in the labor market." 100 He argues that to some extent Blacks, like other subordinated persons, have internalized the existence of discrimination in their decisions or choices to invest in human capital. Existing patterns of discrimination may cause Blacks to invest less in education, ${ }^{101}$ employment programs, and other activities whose

${ }^{99}$ See infra notes $192-93$ and accompanying text.

${ }^{100}$ Sunstein, supra note 47 , at 29.

${ }^{101}$ Elsewhere I have argued that the discriminatory manipulation of evaluative standards causes Black males to overinvest in resources with the potential to lead to a professional sports career and underinvest in those resources that could lead to professional or academic careers. See generally Alex M. Johnson, Jr., How Societal 
payoff is controlled by exogenous market factors than would similarly situated whites. Blacks may opt for this apparently selfdefeating behavior because the expected payoffs from those investments, affected negatively by discrimination, are less than those of similarly situated whites. ${ }^{102}$

Underinvestment in human capital has a greater effect on the Black poor than on wealthier Blacks. To some extent, being a successful Black, at least as measured in terms of income, means making a decision to invest in human capital and seeing that decision pay off. Consequently, no argument is made that Blacks will not invest in human capital; quite to the contrary, the argument is made that those already on the bottom, subject to the worst discrimination and its effects (downtrodden neighborhoods, poor schools, exposure to crime and drugs, and so forth) will recognize that the investment required to overcome their horrific environment is enormous and that the odds of escaping are relatively remote. Thus, they will make little or no investment in the resources that could provide an avenue for escape. Because discrimination is present and affects the market, however, these decisions to invest less in human capital may actually be Pareto efficient or optimal. ${ }^{103}$

One would anticipate that the same phenomenon would occur to some degree with respect to investments in housing. If, as noted above, a large percentage of Blacks are consigned to inferior, segregated housing in a cycle that creates an underclass from which there is little hope of escape, ${ }^{104}$ it makes very little sense for these same Blacks to increase their investments in their homes, either for their own use or for resale.

For those planning to stay in the neighborhood, the externalities $^{105}$ created by the other ghetto dwellers who do not similarly

Evaluative Standards Skew Career Choices and Call for the Aggressive Use of Affirmative Action: "Why Shaquille Chooses to Play Basketball or Tell Jokes Instead of Going to Law School" (Oct. 15, 1994) (unpublished manuscript, on file with author).

102 See Sunstein, supra note 47, at 29 ("Decisions about education, training, drug use, tradeoffs between work and leisure, and employment programs will be affected by existing patterns of discrimination. In a market that contains such discrimination, blacks and women will invest relatively less in such programs.").

${ }^{103}$ See ROBERT COOTER \& THOMAS ULEN, LAW AND ECONOMICS 45 (1988) (describing "Pareto efficiency" as a condition where "there is no way to make a change that benefits someone without harming someone else").

${ }^{104}$ See supra notes 65-69 and accompanying text.

${ }^{105}$ See COOTER \& ULEN, supra note 103, at 45 (" $[\mathrm{A}]$ harmful externality is defined as a cost or benefit that the voluntary actions of one or more people imposes or confers on a third party or parties without their consent."). 
invest in upgrading or maintaining their investment in housing negatively impacts the value of the housing of those who do. That fact, coupled with the almost universal reality that ghetto housing is substandard, supports the idea that it makes little economic sense for the ghetto dweller to invest in maintaining a standard of housing above that of the other ghetto inhabitants; this is a variant of the idea of a "race to the bottom." 106

In contrast, those ghetto residents who do maintain or increase their investment in housing face a suboptimal return as a result of discrimination and its pernicious effects. Instead of reaping a profit upon resale and moving, as per the American dream, to a bigger house in a better neighborhood, discrimination consigns these unfortunate souls to remain forever in a market that does not fully value their investment. ${ }^{107}$ Thus, the cycle of segregated neighborhoods is reinforced by the market, which creates endogenous economic incentives for the maintenance and expansion of such neighborhoods. ${ }^{108}$ Consequently, although the cycle of poverty discussed above may be a factor in perpetuating the ghetto and segregation, the market and the forces it generates must also be recognized as causative factors in the maintenance of segregated residential housing.

The end result of these investment decisions is that the poor remain trapped in the cycle of poverty while the relatively well-off exit at a far greater rate. ${ }^{109}$ As one commentator has observed:

${ }^{106}$ Jonathan R. Macey \& Geoffrey P. Miller, Toward an Interest-Group Theory of Delaware Corporate Law, 65 TEx. L. REv. 469, 469 n.1 (1987) (discussing the origin of the phrase "race to the bottom" in the context of competition among states for corporate chartering revenues and a consequent laxity in corporate law).

${ }^{107}$ Massey and Denton hypothesize that Blacks who attempt to move what I will characterize as "incrementally" in the market- from one level of housing to the next or from one neighborhood (segregated ghetto) to the adjacent integrated neighborhood-are doomed to fail if their goal is to live in a better or integrated neighborhood because frequently the ghetto simply expands to incorporate the adjacent neighborhood that is the target of the incremental move. See MASSEY \& DENTON, supra note 3 , at 70 ("Often black 'suburbanization' only involves the expansion of an urban ghetto across a city line and does not reflect a larger process of racial integration. ${ }^{n}$ ).

${ }^{108}$ See Sunstein, supra note 47, at 29 (noting the existence of this "vicious circle or even spiral" and stating the "[m]arkets are the problem, not the solution").

${ }^{109}$ Some commentators claim that one of the weaknesses of affirmative action is that it awards valuable entitlements to, and thus benefits, those Blacks who need assistance least-individuals at the top of the socioeconomic structure. See, e.g., Stephen L. Carter, Reflections of an Affirmative ACtion Baby 73-80 (1991) (recounting Carter's own experiences as a middle-class Black at Yale Law School; discussing his conflicted feelings about the possibility that he benefitted from an affirmative action admissions program despite the fact that he did not feel 
[T]he extraordinary persistence of blacks and women in attempting to enter professions dominated by whites and men is one of the most striking phenomena of the post-World War II period. Blacks and women frequently appear to invest huge amounts of human capital ... in sectors that treat them inhospitably. In fact, some people in some circumstances [for example, higher income or wealthier Blacks] respond to discrimination by increasing rather than decreasing their investments in human capital. ${ }^{110}$

Those on the margin, the Black middle class on the precipice of success with access to more income, better schools, and better neighborhoods, will be in a better position to invest in human capital or housing. They also have a better chance of making a successful investment given the attributes they begin with in their endeavor.

\section{Synergistic Effects}

Briefly, I have noted Professor Sunstein's observation that in a world plagued by discrimination the labor market produces and reinforces a cycle that leads to underinvestment in human capital. ${ }^{111}$ Moreover, I attempted to demonstrate that this cycle may help create the underclass. ${ }^{112}$ In this subpart, I explore Professor Sunstein's observations on the consequential, or synergistic, effects of market-based (or "economically rational") discrimination on lowincome housing and its tendency to perpetuate segregation.

As Professor Sunstein demonstrates, the market factors discussed thus far, such as the promotion of discrimination by third parties, the presence of statistically or economically rational discrimination, and the resulting underinvestment in human capital,

disadvantaged by his race; and noting that most poor Blacks are not able to reap the benefits of preferential treatment). Intuitively, it seems accurate to presuppose that affirmative action would benefit the best and the brightest. Indeed, it would seem odd if affirmative action programs, say as measured by the LSAT in the law school admissions context, ignored higher-scoring Blacks and benefitted Blacks who scored lower on the test. The fact that the LSAT's highest correlation for performance is socioeconomic status, even across racial lines, suggests that wealthier Blacks will perform better than their poorer counterparts. For a discussion of these and other issues raised by affirmative action in the law school admissions context, see Alex $M$. Johnson, Jr., et al., The Efficacy of Affirmative Action in Legal Education (unpublished manuscript, on file with author).

${ }^{110}$ Sunstein, supra note 47 , at 29-30.

11 See supra notes 100-03 and accompanying text.

${ }^{112}$ See supra notes 107-08 and accompanying text. 
produce significantly more, not less, discrimination. ${ }^{118}$ In a lengthy quote worthy of reproduction, Professor Sunstein notes:

[E]ach of these effects reinforces the others in potentially powerful ways. If there is ordinary prejudice, it will interact with statistical discrimination so as to produce more of both. People notice events consistent with their prejudice and disregard events that are inconsistent with them, and the result will be more in the way of both prejudice and statistical discrimination. . . .

In addition, if there is prejudice and statistical discrimination, and if third parties promote discrimination, there will be decreased investments in human capital. Such decreased investments will be a perfectly reasonable response to the real world. And if there are decreased investments in human capital, then prejudice, statistical discrimination, and third-party effects will also increase. Statistical discrimination will become all the more rational; prejudice will hardly be broken down; consumers and employers will be more likely to be discriminators. ${ }^{114}$

The effect of this synergistic cycle will, once again, fall more harshly on the poor. As Sunstein notes, behavior that is atypical and that does not conform to discriminatory stereotypes is minimized in a way that preserves the stereotype. For example, in this context a discriminating white man might view a successful Black woman living in an integrated neighborhood as atypical and, pardon the phrase, "unblack" or "un-African-American."115 That is, a Black lawyer or doctor who moves into a previously all-white neighborhood is perceived as unblack by her white neighbors. This is "logical" because the very traits that made her successful and capable of moving into an integrated neighborhood-her education, her intelligence, her professional and personal demeanor, her career and the economic benefits that it provides-are used to separate her from her race and her status as a Black. To do otherwise would result in dissonance for these white discriminators who consider Blacks inferior and who must now reconcile their inferiority with living in close proximity (perhaps even adjacent) to the allegedly inferior individual. This rationalization allows white

11s See Sunstein, supra note 47 , at 30-31 (citing a number of market factors that interact with one another and effectively increase the level of discrimination in society).

${ }^{114}$ Id. (emphasis added). it.

${ }^{115}$ Although this latter phrase is inelegant, for the sake of this discussion I will use 
discriminators to hold on to their prejudice and their own subjective view of their self-esteem or status.

Professional or entrepreneurial Blacks are considered inauthentically Black and frequently receive "complimentary" remarks from their white friends such as, "Gee, I don't think of you as Black." This statement, taken in its context, reveals how whites applaud successful Blacks while maintaining the discriminatory belief that Blacks are less intelligent, ${ }^{116}$ less worthy of being coemployees, and less worthy of being neighbors in the abstract. It also reflects the fact that once discriminatory beliefs become entrenched in society, either through law ${ }^{117}$ or practice, ${ }^{118}$ individuals, whether victimizers or victims, adapt to the status quo, internalize its contradictions, and conform their behavior so as to minimize dissonance. ${ }^{119}$

The people who are hurt by this synergistic effect are not the Blacks at the top of the socioeconomic status who are viewed by their white peers as unblack, or the exception to the rule. Rather, those who suffer are the vast majority of the urban poor. This group, the members of which lack the credentials, the education, the access to employment opportunities, and the opportunities for meaningful interaction with whites, makes socioeconomically privileged Blacks less threatening to whites and facilitates their acceptance by whites as unblack members of the community. The urban poor need a vehicle that will lessen or eliminate the negative impact of the third-party effects that promote discrimination, lessen or stop the use of statistically or economically rational discrimination, and slow or reverse the underinvestment in human capital that may be economically optimal on an individual basis, but is wasteful on a social level.

Assuming that the market does not and will not work to lessen or eradicate discrimination, and indeed may, as noted above, reinforce discriminatory behavior in the housing market, ${ }^{120}$ the

${ }^{116}$ For an example of this attitude, see generally MURRAY \& HERNNSTEIN, supra note 28, which attempts to explain why Blacks tend to score lower than whites on IQ tests.

${ }^{117}$ See, e.g., Scott v. Sanford, 60 U.S. 393, 427 (1856) (holding that Blacks are not citizens of the several states "within the meaning of the Constitution of the United States"). The Dred Scott decision was later overturned by the Fourteenth Amendment to the U.S. Constitution. See U.S. CONST. amend. XIV.

${ }^{118}$ See supra part I.A.

${ }^{119}$ See Sunstein, supra note 47 , at 31-32.

${ }^{120}$ See supra notes $111-14$ and accompanying text. 
use of the law and the concomitant acceptance of the interventionist model to correct discriminatory behavior may at first glance seem to be the appropriate vehicle to combat discrimination in fields like housing. It is to that model that I now turn.

\section{E. The Interventionist Model}

Antidiscrimination laws represent an alternative method for combatting discrimination. Those who support this interventionist model point to the market model, which features a lack of intervention, and allege that its failure to eradicate or significantly to lessen housing discrimination ${ }^{121}$ justifies the use of intervention model to combat discrimination.

A major component of this thesis, known as the adaptive preference model, is that the law is, but should not be, neutral in facilitating market transactions because the imposition of legal rules creates endogenous preferences that are influenced by the choice of legal rules. ${ }^{122}$ Cogently summarized, the gist of the adaptive preference model is that preferences are heavily influenced by the choice of legal rules used to regulate social behavior. If whites are prohibited from discriminating against Blacks in housing by the Fair Housing Act, they will learn over time "to 'adapt' their preferences" to conform to the law. ${ }^{123}$ Thus, society can use the law as a positive tool to lessen or eradicate discrimination, rather than rely on the invisible hand of the market.

This model has much explanatory power and much support. Intuitively it seems correct that individuals will shape or alter their behavior to conform to the law. Although the theory has come under attack recently for its tautological character and its failure to specify which preferences should be enforced by the law, ${ }^{124}$ it

${ }^{121}$ See supra part II.A.

122 The adaptive preference theory was first put forth in JON ELSTER, SOUR GRAPES: STUDIES IN THE SUBVERSION OF RATIONALITY (1983) (discussing various forms of rationality and discerning which preferences would exist in a well-ordered society), and first found its way into the legal literature in Sunstein, supra note 79, at 1146 ("The phenomenon of adaptive preferences results from the fact that what people want is sometimes a product of what they can get.").

${ }^{123}$ Richard A. Epstein, Two Conceptions of Civil Rights, SOC. PHIL. \& POL'Y, Spring 1991 , at 38, 50 (citation omitted).

124 See id. at 52 ("The hard question is which behaviors the law should seek to legitimate with its imprimatur. A theory of adaptive preferences may give some weak clues about individual response to legal rules, but it affords no insight as to which rules are justified or why."). 
seems quite powerful once society has determined these preferences. Moreover, I am willing to assume that the elimination of discrimination is a preference that all reasonable persons would support. ${ }^{125}$

The problem, of course, with the adaptive preference or interventionist model is not that the preference is not agreed upon or subject to dispute. Quite simply, the problem is that the model has not worked. As noted in Part I, housing discrimination has not significantly improved in the thirty years since the enactment of the Fair Housing Act, nor has meaningful integration been achieved since the ruling in Brown $v$. Board of Education. ${ }^{126}$ That leads to a question of whether the interventionist model is a viable method to eradicate discrimination or whether it should be replaced with another model. If it is retained, then its flaws must be exposed and corrected. If they cannot be, the interventionist model should be jettisoned.

The problem with the interventionist model, and with the adaptive preference theory that undergirds it, is not the theory itself, but rather the conflict in the preferences that has heretofore gone undetected and unexplained. To be effective, the adaptive preference model depends on the articulation and publication of a clear message whose value can be internalized and acted upon. The problem with the interventionist model is that the message articulated and publicized by edicts like the Fair Housing Act are inconsistent with other long-standing preferences established in the law. Instead of establishing a clear preference, antidiscrimination edicts conflict with the message perpetuated through the continued maintenance and operation of fixed racial categories-a message that

${ }^{125}$ This may be where Professor Epstein and I part. An argument can be made, I assume, that discrimination is efficient if the gains obtained by the dominant group, whites, outweigh the loss suffered by the minority group, Blacks. Perhaps that is why American society does not adapt to the antidiscrimination preference in the Fair Housing Act.

I reject that rationale for two reasons. First, it is difficult to measure the gains and losses in this context because it presupposes that the market works perfectly, which is not the case. See supra notes 107-08 and accompanying text. Second, and more importantly, it violates moral and philosophical precepts upon which this democracy and western society are founded. See, e.g., JOHN RAWLS, A THEORY OF JUSTICE 3 (1971) ("Each person possesses an inviolability founded on justice that even the welfare of society as a whole cannot override.").

${ }^{126}$ See supra part 1. For a further discussion of the failure of integrationism, see Johnson, supra note 5, at 1402-03 (noting the failure "to recognize and appreciate the social realities that preclude the attainment of meaningful integration through simple judicial or legislative fiat"). 
supports the thesis that racial categories and race continue to matter in contemporary American society.

To the extent that the new antidiscrimination preference trumps the older discrimination preference, it does so only for economically advantaged Blacks, for several reasons. First, those whites who would internalize the newer preference are those who have the capacity to incorporate the new preference most efficiently. They do so because they are smarter, have access to better information, and, as a logical corollary, have more wealth. More importantly, those advantaged whites who internalize the message have less to lose. They are protecting more assets than a property right in whiteness. ${ }^{127}$ That right is less relevant because they have access to other rights and entitlements.

As long as the law continues to classify individuals as white and Black based on rules such as the one drop of blood rule, ${ }^{128}$ however, the message that race matters will continually be reinforced in this society. Indeed, it is logical to assume that important things such as entitlements must turn on that characterization because we strive so mightily to maintain the racial distinction between whites and Blacks. This inevitably leads to discriminatory behavior because these distinctions-that is, differences-are recognized and valued.

One way to explore my contention is through an analysis of other subordinated persons of color and related immigrant groups in American society who are also dominated by whites, in order to demonstrate the power of the one drop of blood rule, phenotype, ${ }^{129}$ and racial discrimination. As I explain more fully elsewhere, I contend that, because of both an absence of ethnicity and a visible phenotype that largely precludes assimilation, Blacks face a more intense form of discrimination than other racial groups that is more difficult to escape. ${ }^{130}$

My first contention is that Blacks largely lack an ethnic identity that is available to whites. Subgroups of Italians, Poles, Irish, and others exist and flourish within the white race, and these groups are valued by society. Blacks are not allowed to have ethnicity, however,

${ }^{127}$ For a discussion of whiteness as a property right or interest, see infra part III.

${ }^{128}$ See supra note 23 and accompanying text.

${ }^{129}$ Phenotype indicates the amalgamation of observable, visible traits possessed by an individual. See JAMES C. KING, THE BIOLOGY OF RACE 20 (1981) (defining the term in the context of examining race from a biological perspective).

${ }^{130}$ See Johnson, supra note 24, at 25. 
because there are no differences recognizable among Blacks. They are all simply viewed as "other" by whites, irrespective of their ethnicity. ${ }^{131}$

Secondly, the amount of melanin in one's skin, which is what I am referring to when $I$ use the term phenotype, is a visibly observable trait that allows an individual to categorize others easily and quickly. The two predominant categories are white and Black, and, given the one drop of blood rule, white is measured by the absence of Black blood or Black ancestors who could have created the Black phenotype: Thus, the amount of melanin in one's skin determines who is white and who is not, ${ }^{132}$ although even the smallest amount is enough to place one in the Black box. That precludes easy assimilation for the vast majority of Blacks. ${ }^{133}$

Consequently, Blacks, unlike other minorities and immigrant groups, face a different sort of housing discrimination than other minority and immigrant groups because the discrimination they must contend with is based on a factor that is not present in those other groups. ${ }^{134}$ The transaction costs required to keep Blacks

${ }^{131}$ My contention, which I flesh out more fully in my article, Destabilizing Racial Categorizations Based on Lessons from Trademark Law, supra note 24, is that Blacks from the Caribbean, Blacks from South America, and even Blacks from the rural southern United States are different ethnically from urban Blacks residing in the United States, and that this ethnicity should be acknowledged and recognized by whites as well as Blacks.

132 What is astounding about American racial classifications is that the Black/white classificatory scheme is dichotomous. There is no mixed-race or other category that classifies the product or progeny of a miscegenistic union. That offspring or prodigy would be classified under the one drop of blood rule as a Black.

133 It goes without saying that a few Blacks do become assimilated by "passing." See infra notes 178-81 and accompanying text. It must also be recognized, however, that passing is a relatively unique phenomenon and does not afford the same opportunity to Blacks as it does to immigrant groups and other minorities, such as white Hispanics, who are not phenotypically Black and can therefore more easily assimilate into white society.

What is puzzling in this context is how Hispanic- and Asian-Americans, who are also phenotypically distinct but in a different way, are able to assimilate and integrate into American neighborhoods to a greater degree than African-Americans. See infra notes 149-50 and accompanying text. For an answer to this question, see Johnson, supra note 24, at 54 (noting the problems with multiracial categories from the perspective of a biracial analysis).

${ }^{134}$ Once again, this is puzzling because the same treatment does not apply to Asian-Americans, the so-called "model minority." For a discussion of this fallacious characterization, see Chew, supra note 26 , at $24-45$ (discussing the myth that AsianAmericans are treated as "model" minorities and therefore do not experience the hostility that Blacks do); see also Johnson, supra note 24, at 34-40 (discussing people's perceptions of physical characteristics of race). 
separate are, as a result, lower than the costs associated with respect to these other groups. Finally, the same feature that characterizes Blacks as a minority group also easily identifies them as individuals to be excluded from the community.

Evidence gathered from the experience of other minority and immigrant groups, including Asian-Americans, bears out the thesis that Blacks, because of the manner in which they are defined by the one drop of blood rule and the manner in which their phenotype precludes easy assimilation into the mainstream, white melting pot, ${ }^{135}$ also experience a different form of segregation far more potent than that experienced by other similarly situated groups.

As Massey and Denton point out, the segregation of Black Americans is a unique phenomenon in American history. It is unique not because Black ghettos developed recently, but because Blacks, unlike other immigrant and minority groups ${ }^{136}$ who have experienced the ghetto at some point before their assimilation in American society, have remained in the ghetto and have experienced the degree of hypersegregation addressed above. ${ }^{137}$ For example, Hispanics, irrespective of socioeconomic class, are much more integrated into American cities than are Blacks. ${ }^{138}$ The same, and perhaps even stronger, claim can be made for AsianAmericans. ${ }^{139}$

Any interested party must address why other immigrant groups are treated differently than their Black counterparts when it comes

${ }^{135}$ For a discussion of the unique barriers that Blacks face in assimilating racially into American society, see infra note 140 and accompanying text.

${ }^{136}$ I expressly omit a discussion of the plight of Native Americans and other indigenous peoples because of a lack of data and my assumption that the United States' previous policy of interning such peoples on reservations would skew any such data regarding the voluntary or involuntary nature of segregation.

${ }^{137}$ See supra notes 25-26 and accompanying text. For a discussion of the hypersegregation faced by Blacks, including recent statistics, see supra notes $37-41$ and accompanying text.

${ }^{138}$ See MASSEY \& DENTON, supra note 3, at 77 ("Despite their immigrant origins, Spanish language, and high poverty rates, Hispanics are considerably more integrated in U.S. society than are blacks.").

${ }^{139}$ See id. at 87. In their survey of the San Francisco-Oakland metropolitan area, which contains the largest concentration of Asians in the United States, Massey and Denton observed that

the Asian-white segregation index fell from 64 in the lowest income category to 52 in the highest (compared with respective black-white indices of 86 and 79). These contrasts were repeated in cities throughout the United States: ... Asian segregation generally begins at a relatively modest level among the poor and falls steadily as income rises.

Id. 
to residential housing patterns and must identify the cultural factors (racism, poverty, the creation and maintenance of an underclass and its resultant pathology of crime, illegitimacy, undereducation, and governmental dependency) that produce this disparate treatment. One obvious response is the intense discrimination that Blacks confront in the housing market. Discrimination, like other irrational preferences, does not appear in a uniform fashion with respect to all targeted groups.

Hence, given the unique position of Blacks in American society resulting from their enforced enslavement and subsequent incorporation (not integration) into American society, one finds a hierarchy of discrimination whereby different groups suffer differential degrees of discrimination, with whites at the top of the hierarchy and Blacks on the bottom. ${ }^{140}$ Other minorities, such as AsianAmericans or Hispanic-Americans, fall somewhere in the middle. ${ }^{141}$

Legal rules must recognize that this hierarchy of race exists and that it has a correspondingly hierarchical impact on housing opportunities based on racial or ethnic group identity. Once the law has recognized this fact, it must create a preference for antidiscrimination without reifying racial distinctions through the guise of respecting racial differences. This goal can be accomplished by destabilizing stable and fixed racial classifications. ${ }^{142}$ This is the best way to help the urban poor, both white and Black, who are the victims of these classifications.

Before turning to destabilization, however, Part III details how stable racial classifications have created a property right in white-

${ }^{140}$ To defend such a thesis, however, would require a substantial investigation to establish that favored and disfavored minorities exist, and that those in the position to discriminate-whites-make conscious discriminatory choices based on the ethnic or racial makeup of the individual or group being discriminated against. Such an argument is beyond the scope of this Article. Instead, I argue that Blacks are differentially discriminated against because they are less able to assimilate and integrate themselves into white American society than other minorities based on their phenotype and other visible characteristics. See infra notes $177-83$ and accompanying text (suggesting that racial segregation reinforces categorizations that are increasingly difficult to base solcly on physical characteristics, and discussing the phenomenon of "passing").

111 Some commentators, however, suggest that the extent of discrimination suffered by so-called "model" minority groups such as Asian-Americans is no different than that suffered by Blacks. See, e.g., Chew, supra note 26, at 8-24 (noting the many instances of discrimination against Asian-Americans, including "lynching[s], race riots, and slavery").

${ }^{142}$ See infra part IV. 
ness that whites (poor whites in particular) seek to protect, in part, through the maintenance of segregated neighborhoods.

\section{WHITENESS AS PROPERTY AND ITS IMPACT ON THE URBAN POOR}

It really is quite remarkable: Blacks live with Blacks and whites live with whites. ${ }^{143}$ Metaphorically one might imagine these two communities in the following way: Picture a black circle representing the Black community and a white circle representing the white community. The white circle is significantly larger than the black circle. Neither circle overlaps. Now picture a green circle representing socioeconomic status. This circle is roughly the same size as the white circle. Unlike the other two fields, however, the green circle is multishaded. The center of the circle is light green; toward the circumference, the circle becomes a darker, more verdant shade of green. The light green shade represents a relatively low level of socioeconomic status, whereas the dark green shade represents a relatively high level of socioeconomic success.

If one places the green circle over the white circle, one sees that the white community is relatively evenly distributed between the light center of the green circle and the more verdant outer rim. When one places the green circle over the black circle, however, one sees that the light center of the green circle covers almost all of the black circle. The portion of the black circle that is covered by the darker, more verdant portion of the green circle is minuscule.

If these overlapping circles represent neighborhoods, what one finds is that, where the dark portion of the green circle overlaps with the black circle (DGB for Dark Green Black) and the dark outer rim of the green circle overlaps with the white circle (WDG for White Dark Green), the dark portion of the green circle that covers both the black (DGB) and white (WDG) circles represents an

${ }^{143}$ I reiterate that my focus on Blacks to the exclusion of other minorities in no way diminishes or ignores the segregated residential patterns experienced by other subordinated groups in American society. Residential segregation negatively impacts all subordinated groups to some extent; however, Blacks are the dominant and prototypical minority group and, as discussed previously, Blacks face a higher degree of segregation than other minority groups. See Douglas S. Massey \& Nancy A. Denton, Trends in the Residential Segregation of Blacks, Hispanics, and Asians: 1970 1980, 52 AM. Soc. REv. 802, 817-23 (1987) (examining the reasons behind the relatively high level of Black segregation as compared to Hispanic and AsianAmerican segregation); see also supra notes 37-41 and accompanying text (discussing hypersegregation and its effects on Blacks). 
integrated neighborhood. In other words, where the DGB and the WDG circles intersect, one finds relatively wealthy Blacks living with relatively wealthy whites. What is puzzling, of course, is why the LGB (or light green black) and the LGW (or light green white) circles do not overlap to any significant extent. Given the capitalistic nature of our society and the prevalence of poor rather than rich individuals, one would expect the LGB and the LGW circles to overlap significantly. ${ }^{144}$

Indeed, many scholars find it remarkable that poor whites and poor Blacks do not live in racially integrated neighborhoods. ${ }^{145}$ Nevertheless, much of the scholarship produced by the leading empiricists in the field supports the tentative conclusion that the level of individual socioeconomic status is largely irrelevant to the level of racial integration. ${ }^{146}$

Massey and Denton, in their pioneering work, have taken a rather odd approach to this issue by analyzing the race and class issue from the perspective of upper- or higher-income Blacks. By examining the alleged lack of integration of higher-income Blacks into wealthy white neighborhoods, Massey and Denton conclude that race dominates over class and that socioeconomic status is irrelevant as a correlative or variable in explaining the extent of segregation or, conversely, the absence of integration:

14 See MASSEY \& DENTON, supra note 3, at 84 ("In the market-driven, statusconscious society of the United States, affluent families live in different neighborhoods than poor families, and to the extent that blacks are poor and whites are affluent, the two groups will tend to be physically separated. ..."). Because the poor live with the poor and the rich live with the rich, and there are clearly more poor than rich persons, one would expect to see more integration amongst the poor. Moreover, because, according to the Statistical Abstract of the United States 1994, approximately $12 \%$ of whites (about 25 million people) and roughly $33 \%$ of Blacks (about 10 million people) have household incomes below the poverty level, one would expect to see these 35 million poor individuals living in dilapidated but integrated housing. See U.S. BuREAU OF THE CeNSUS, U.S. DEP'T OF COMMERCE, STATISTICAL ABSTRACT OF THE UNITED STATES 1994, at 17, 48 (114th ed. 1994) (reporting U.S. population by race and socioeconomic characteristics of the white and Black populations as of the end of 1992, the latest year for which accurate figures are available).

145 See, e.g., Potter, supra note 15, at 1169 ("This finding does not correspond with the theory that racial housing patterns are attributed to income differences. If income were a primary factor, racial diversity would be highest in lower income communities.").

${ }^{146}$ See MASSEY \& DENTON, supra note 3, at 240-41 n.28 ("Because racial segregation does not decline with rising socioeconomic status, out-movement from poor black neighborhoods certainly has not been to white areas."). 
[W] hen one considers residential segregation, ... race clearly predominates. ... Even if black incomes had continued to rise through the $1970 \mathrm{~s}$, segregation would not have declined: no matter how much blacks earned they remained spatially separated from whites. In 1980, as in the past, money did not buy entry into white neighborhoods of American cities. ${ }^{147}$

Massey and Denton's focus on economically privileged Blacks and the alleged failure of these individuals to integrate white communities is particularly puzzling because of the relatively small number of wealthy Blacks. ${ }^{148}$ The more interesting question is why poor whites and poor Blacks do not live in integrated communities. Accepting for a moment Massey and Denton's thesis that economic success does not lead to integration because of racism, the conclusion that racism prevents the integration of poor neighborhoods is not obviously true.

Massey and Denton's conclusion that race, rather than class, is the key factor leading to segregated neighborhoods supports the thesis that the racial typologies that define racial classifications are the primary factors that lead whites of all socioeconomic classes to discriminate against Blacks and establish segregated housing patterns. Furthermore, Massey and Denton's conclusion that even the poorest Hispanic- and Asian-Americans experience less segregation in many large U.S. cities than the most affluent Blacks ${ }^{149}$ is consonant with my thesis that the one drop of blood rule creates a property right in whiteness that whites protect by maintaining an artificial dichotomy between whites and Blacks based on phenotype to which no other minority group is subject. ${ }^{150}$

${ }^{147} I d$. at 85 .

${ }^{14}$ Only $16.1 \%$ of Black families (equalling approximately 1.3 million persons) earned over $\$ 50,000$ for the year 1992 , as compared to $35.8 \%$ of white families (equalling approximately 20.7 million persons). See U.S. BUREAU OF THE CENSUS, supra note 144, at 48.

${ }^{149}$ See MASSEY \& DENTON, suṕa note 3, at 87 (stating that "Hispanic and Asian segregation generally begins at a relatively modest level among the poor and falls steadily as income rises"); see also supra notes $133-41$ and accompanying text (discussing the different experiences of Blacks in U.S. cities relative to other minority groups).

${ }^{150}$ The maintenance of a rigid color line between whites and Blacks based on the one drop of blood rule precludes easy assimilation of Blacks into white society, an option that Hispanics, who may be of any race, possess. See MASSEY \& DENTON, supra note 3, at 62; see also infra part IV. Likewise, the phenotype or skin color of most Asian-Americans is similar to that of whites. As a result, whites may be more accepting of Asian-Americans than of Blacks. But see Chew, supra note 26, at 24-25 (describing problems unique to the Asian-American community, such as overgeneral- 
Massey and Denton's thesis may be flawed, however, to the extent that it does not capture the effect that income, and what it signifies to whites, has on discrimination, and what that means for the different experiences of poor Blacks and their relatively wealthier counterparts. The differential experience between poor and wealthy Blacks suggests that the key to explaining the continued persistence of segregated neighborhoods thirty years after the enactment of the Fair Housing Act is racial identification. ${ }^{151}$

Taking Massey and Denton's data at face value, it proves too little. Their sweeping conclusions about race and class and the lack of integration for all Blacks, including high-income Blacks, do not take into account Massey and Denton's own work demonstrating that more affluent white neighborhoods contain a higher percentage of Blacks than white working class (poor) and middle-income communities. ${ }^{152}$ Thus, although the power of racism may explain why Blacks remain segregated, it does not explain why Blacks are generally accepted more readily in white affluent neighborhoods than in poor ones.

Consequently, I wish to modify Massey and Denton's thesis to acknowledge that race is still the predominant factor that causes segregation. Massey and Denton attempt to demonstrate that segregation is an intensifier of poverty. ${ }^{153} \mathrm{I}$, on the contrary, posit that the existence of wealth, because of the attributes associated with it, and the signals it sends to monitoring whites about the ethnicity of the individual and the degree to which that individual has been assimilated, ${ }^{154}$ serves as a vehicle through which a limited number of Blacks do move into and integrate affluent white communities.

Moreover, it is not inconsistent with the theory that racism is the predominant variable that brings about and perpetuates segregation to presuppose that socioeconomic status presents different integrative opportunities and experiences for wealthy and poor Blacks. Along that line, it is not surprising that there is "less racism" in affluent rather than poor and middle-class white communities. ${ }^{155}$ Given the sheer numbers of poor and middle-class

ization and negative stereotyping of social/behavioral characteristics).

${ }^{151}$ See supra notes 116-19 and accompanying text.

152 See Douglas S. Massey et al., The Effect of Residential Segregation on Black Social and Economic Well-Being, 66 SoC. Forces 29, $41-44$ (1987) (analyzing data compiled during the 1980 census in Philadelphia).

${ }^{153}$ See MASSEY \& DENTON, supra note 3, at 118-25.

${ }^{154}$ See supra notes 115-19 and accompanying text.

155 See, e.g., Potter, supra note 15, at 1169 (suggesting that affluent whites do not 
Blacks and the relatively small number of affluent Blacks, ${ }^{156}$ it stands to reason that wealthy whites can be less racist because the "market" will do the exclusionary work for them.

Furthermore, when the economic success of the affluent Black is viewed as positively correlated to assimilation into white norms and values (that is, the Black is not a "gang-banger" or an unemployed "welfare cheat" who will drive down property values), the racial identification and its threat to the white community's values become subsumed. The class standing of those individuals situated within the community provides prestige that precludes the need for other forms of group identification or assimilation. In other words, merely being a resident of Danbury, Connecticut, San Francisco, California, or Bergen-Passaic, New Jersey ${ }^{157}$ may be enough of an indicia of attainment and success that racial identification becomes largely irrelevant. Green, and I mean money, rather than black or white, becomes the operative color that builds solidarity and promotes exclusivity.

The transformative effects of economic status, combined with the fact that the educational levels of those in affluent communities may reduce racism, ${ }^{158}$ leads to the conclusion that the experiences of wealthy Blacks, or at least the opportunities afforded to wealthy Blacks, are different than those of their poorer counterparts. In this respect, money whitens. ${ }^{159}$ What it fails to fully explain is why

feel threatened by Black entry into their communities because they realize few Blacks will have the economic ability to do so).

${ }^{156}$ For example, the percentage of Black families that have household incomes below the poverty rate is $33.1 \%$, whereas the percentage of similar white families is 12.2\%. See Margaret L. Usdansky, Few Feel Economic Rebound, USA TODAY, Oct. 7, 1994, at 2A; supra note 144; see also Judith L. Howard \& Gregory Katz, Finding Common Ground: U.S. Integration Problems Foreshadow Challenge for South Africa, DALlas MORNING NEWS, Nov. 15, 1992, at 22 ("Nationwide, census data also show a worsening split between the black poor and the black affluent. Recent figures show that although the percentage of high income black families in 1990 had more than doubled since 1967, the proportion of blacks in the lowest income groups grew by 50 percent."); see also U.S. BUREAU OF THE CENSUS, supra note 144, at 17, 48 (presenting similar figures on the number of Black households below the poverty level).

${ }^{157}$ Danbury, San Francisco, and Bergen-Passaic are three relatively affluent U.S. communities. See, e.g., Seattle Area Ranks 27 th in Per-Capila Income, SEATTLE TIMES, May 4, 1990, at D7 ("The area in Connecticut comprising Bridgeport, Stamford, Norwalk and Danbury retained its top ranking, with per-capita personal income of $\$ 29,084$... Following the Connecticut suburbs of New York City were San Francisco, \$26,309; Bergen-Passaic, N.J., \$25,388 ...").

${ }^{158}$ An inverse correlation between level of educational attainment and racism has been documented. See Massey et al., supra note 152, at 53 (presenting survey data showing that prejudice decreases with education).

${ }^{159}$ See F. JAMES DAVIS, Who Is BLACK? ONE NATION'S Definition 101 (1991). 
poor whites feel threatened by the prospect of living with similarly economically situated poor Blacks. The fact that there are more Blacks who are willing and able to live in these neighborhoods (the sheer threat of numbers) does not explain why these whites are so hostile to the entry of any Blacks. Potter also notes the paradox that is at the center of my Article:

[U]pper classes do not feel threatened by black entry, since they realize that few blacks possess the resources to move into the most affluent communities. In contrast, lower and middle income whites do feel threatened by blacks as they realize that blacks possess both the economic means and the desire to assimilate into the lower and middle income areas. ${ }^{160}$

Thus, although numbers may explain why the "integration threat" is less credible for wealthier whites, it does not explain the continued existence of this perceived threat. More importantly, it does not explain the behavior of poor whites, who almost fervidly defend their segregated neighborhoods against racial minorities and who rapidly flee when one or two Black households move into these previously all-white areas. ${ }^{161}$ For an explanation, I turn to a theory in which whiteness is viewed as a property right that whites seek to preserve via segregated neighborhoods. Viewing whiteness as a property right sheds light on why poor Blacks and poor whites do not inhabit the same area and why poverty intensifies segregation. ${ }^{162}$

The contention that whiteness is a valuable property right is not a new or novel claim. The vigor with which white neighborhoods

Davis notes that, in Brazil,

as people climb the class ladder by educational and economic success, their racial designations often change. No secrecy or change of residence is needed to "pass" to another racial identity, and it is a common aspect of upward mobility. ... [C]lass can have more weight than physical traits in determining racial classification. Brazilian census estimates for racial categories thus provide better information on the class structure than on racial composition ....

Id.; see also SOWELL, supra note 30, at 101 ("As in much of Latin America, wealth facilitated acceptance as 'white' [in Brazil], and at one time official certificates of whiteness were for sale.").

${ }^{160}$ Potter, supra note 15, at 1169 (citing Massey et al., supra note 152, at 51).

161 See MASSEY \& DENTON, supia note 3, at 38 ("Given the intensity of black demand and the depths of white prejudice, the entry of a relatively small number of black settlers would quickly surpass the threshold of white tolerance and set off a round of racial turnover.").

${ }^{162} C f$. id. at $118-25$ (contending that segregation intensifies poverty and not vice versa). 
protect the whiteness of their communities is clear evidence that whiteness has value, at least to whites. ${ }^{163}$ This notion that whiteness is a very valuable property right worthy of protection has also been the subject of legal discourse in academia. ${ }^{164}$

Although whiteness may appropriately be viewed as a property right, the benefits associated with that right are not necessarily material in an economic sense. ${ }^{165}$ My supposition is that poor whites cling to and protect their whiteness as a mark of distinction because it is the only significant and viable asset they possess. ${ }^{166}$

The notion of residential integration challenges that whiteness. The homogeneity of the neighborhood's racial identity reinforces the privilege created by the property right in whiteness. Having no other significant asset, poor whites gain a benefit from maintaining their separate status. They can operate under the fiction that they choose to live without Blacks. That choice, and the power that it gives them, is what is protected by the urban white poor in maintaining segregated neighborhoods.

Having the same or less socioeconomic status as other Blacks is, in effect, negated by the "privilege" of living in a segregated neighborhood with other whites. Living in a separate community creates a market premium that not only provides a benefit to its white inhabitants but also reinforces the attribute that provides the premium. In this way, the poorest white enjoys a privilege that is

${ }^{163}$ Cf. Gotanda, supra note 8, at 59-60 (arguing that complete assimilation of all races would be "cultural genocide").

${ }^{164}$ See, e.g., Frances L. Ansley, Stirring the Ashes: Race, Class and the Future of Civil Rights Scholarship, 74 CORNELL. L. REV. 993, 1024 n.129 (1989) (arguing that under the current political, economic, and cultural system whites "overwhelmingly control power and material resources"); Derrick Bell, Xerces and the Affirmative Action Mystique, 57 GEO. WASH. L. REV. 1595, 1602, 1608 (1989) (noting that affirmative action policies threaten the property interests enjoyed by whites); Harris, supra note 8, at 1707 (discussing the negative effects of the concept of whiteness as a property value).

${ }^{165}$ See Harris, supra note 8, at 1741 (" $[E]$ ven when the white working class did not collect increased pay as part of white privilege, there were real advantages not paid in direct income: whiteness still yielded what Du Bois termed a 'public and psychological wage' vital to white workers." (citing W.E.B. DU BOIS, BLACK RECONSTRUCTION 700 (photo. reprint 1976) (1935))).

${ }_{166}$ See id. at 1743-44. Professor Harris argues:

Owning white identity as property affirmed the self-identity and liberty of whites and, conversely, denied the self-identity and liberty of Blacks. . . . The concept of whiteness was carefully protected because so much was contingent upon it. Whiteness conferred on its owners aspects of citizenship that were all the more valued because they were denied to others.

Id. 
superior to the wealthiest Black and, more importantly, one that can be destroyed by living in proximity with poor Blacks.

Professor McAdams's work on cooperation and conflict supports this thesis. ${ }^{167}$ After establishing that members of socially connected groups, those with a "shared trait" such as whiteness, cooperate to produce intragroup status and esteem, ${ }^{168}$ Professor McAdams makes a point that is integral to the maintenance and existence of segregated neighborhoods, arguing that the flip side of intragroup cooperation (between whites) is the facilitation of intergroup competition (whites versus Blacks) and conflict.

Given intra-group cooperation, there will be more inter-group conflict. Status is both an additional means of ensuring intra-group cooperation and a new end of intra-group cooperation, and in both ways it contributes to conflict between groups. Given that social groups are often in material conflict, the desire for intra-group status means that individuals will cooperate more effectively in such disputes, i.e., groups will be more effective "combatants" whenever material conflict arises. More importantly, the very mechanism that facilitates greater intra-group cooperation will ensure a new form of conflict: competition for inter-group status. ${ }^{169}$

Race-that is, whiteness-is the vehicle through which social status or esteem is achieved. ${ }^{170}$ In order to maintain its value it must be protected. One vehicle for maintenance is the use of segregated neighborhoods in which members contribute materially to intragroup status by refusing to sell or live in proximity to Blacks and, to a lesser degree, other minorities. Moreover, segregated neighborhoods enhance the property right in whiteness because the very exclusivity of the neighborhood (the fact that no blacks live there) raises the intergroup status of whites, thereby lowering the intergroup status of Blacks who are excluded because of their perceived inferior racial status. ${ }^{171}$

${ }^{167}$ See McAdams, supra note 21, at 25-26 (arguing that, because individuals recognize that their social esteem is based on evaluations of the groups with which they share observable traits, they are concerned that their groups be held in esteem, particularly in relation to other groups).

${ }^{169}$ See id. at 37 ("[I]ndividuals care particularly for esteem within their sociallyconnected groups; even without a central authority, individuals tend to provide esteem to those who contribute to the welfare of such groups; and this process of esteem allocation facilitates wider social norms that directly and indirectly bring about further cooperation.").

${ }^{169} \mathrm{Id}$. at 38.

${ }^{170}$ See supra note 140 and accompanying text.

${ }^{171}$ See McAdams, supra note 21, at 60 (arguing that the recognition of differences 
Professor McAdams postulates that the discriminatory and racist behavior that creates segregated neighborhoods is "an especially virulent and pathological form of status production . . . by which one group seeks to produce esteem for itself by lowering the status of another group." 172 Neighborhoods become an important vehicle both for the production of the shared trait and, more importantly, in overcoming free-rider problems that have the potential for destroying the status produced by the shared trait. ${ }^{173}$ Racially segregated neighborhoods, therefore, act as efficient vehicles for the production of racial discrimination because by aligning the social and trait-groups in a defined geographic space they eliminate free-rider problems.

Moreover (and consonant with my thesis), in the status production model discrimination is "an investment in the production of status." 174 As such, it is a cost-effective investment for poor whites, who, by refusing to live in integrated neighborhoods, acquire and maintain self-esteem in their interest in whiteness. McAdams argues that housing and employment discrimination constitute "the most productive means of subordination and therefore induce the greatest 'investment' by whites. . . . [E]xcluding blacks from neighborhoods is not only a very public symbol of their subordinated status, but denies to them the material benefits of reciprocity that may arise among neighbors. ${ }^{175}$ Indeed, because whiteness may be the only significant asset lower-class whites possess, they may allow wealthier whites to free ride on their discriminatory behavior even as these wealthy whites decry such behavior. ${ }^{176}$

Segregated neighborhoods also enhance or reinforce the way that racial categorization establishes the intragroup's shared trait of whiteness. As long as racial classification remains dichotomous,

based on phenotype (race) creates a group identification and status that is enhanced by lowering the status of individuals possessing different phenotypical traits).

172 Id. at 58.

${ }^{173}$ See id. at $62-63$ (arguing that social connection eliminates the free-rider problem).

${ }^{174}$ Id. at 85 (emphasis omitted).

175 Id. at 106.

${ }^{176}$ See id. at 93 (arguing that "high-status whites who condemn low-status whites for their discrimination may gain more" by doing so "than by investing in the subordination of ... minorities," and positing that "certain classes of whites may enjoy free-riding on the status other whites secure and then further increase their status by subordinating those whites for being discriminatory"). 
dividing people into whites and others, ${ }^{177}$ some way of defining the shared trait that characterizes the white intragroup is necessary. Within the wide variety of skin tones or phenotypes, there are individuals who visually are "racially indeterminate." I contend that in a world without fixed racial classifications, defining who is white and, conversely, who is other or nonwhite, is not as easy as it might seem. Consider the phenomenon of "passing," in which individuals who would be classified as Black pursuant to the one drop of blood rule pass as whites based on their phenotype. Racially segregated neighborhoods, however, provide and reinforce racial definitions or categorizations that, to an extent, preclude passing. An individual from an inner-city ghetto is presumed to be Black irrespective of phenotype. Similarly, one residing in an all-white suburb is presumed to be white based on residence. Thus the instability of racial definitions based on phenotype, which in turn destabilizes the one drop of blood rule, leads quite naturally to the use of proxies to determine who is authentically white and who is not. Because phenotype alone does not automatically consign individuals into one group or the other, the desire to make sure that individuals are assigned to certain groups creates policing problems. Residence in certain neighborhoods serves as an easy vehicle with which to police racial boundaries.

My contention might seem improbable at first glance, but a lengthy quote, worthy of repeating, captures the essence of my claim:

Though [Woody] often proclaimed his blackness, and though he had a Negro grandparent on each side of his family, he nevertheless looked to all the world like your typical white boy. Everyone, on first meeting him, assumed as much. I did, too, when we began to play together nearly a decade earlier, just after I had moved into the middle-class neighborhood called Park Manor, where Woody's family had been living for some time.

There were a number of white families on our block when we first arrived; within a couple of years they had all been replaced by aspiring black families like our own. I often wondered why Woody's parents never moved. Then I overheard his mother declare to one of her new neighbors, "We just wouldn't run from our own kind," a comment that befuddled me at the time. Somewhat later ... my mother explained how someone could be black though he or she looked white. She told me about people

${ }^{177}$ See infra notes 184-92 and accompanying text. 
like that in our own family-second cousins living in a fashionable suburb on whom one would never dare simply to drop in, because they were "passing for white." ... It dawned on me after this conversation with my mother that Woody's parents must have been passing for white in preintegration Park Manor. The neighborhood's changing racial composition had confronted them with a moment of truth. ${ }^{378}$

"Passing" is a phenomenon with which many Blacks are familiar. As noted above, passing occurs when a Black with visibly white features, such as fair skin and straight hair, passes herself off as a white person. ${ }^{179}$ This act of racial self-denial and abdication was a consequence of the positive value, and all the rights and privileges pertaining thereto, associated with whiteness. ${ }^{180}$

Hence, preserving racial identity in a world in which passing becomes possible-a world in which phenotype does not correlate with the one drop rule-creates error costs in maintaining and assigning racial classifications. When some are defined as Black by the one drop of blood rule, but are visibly white, problems arise. From the other perspective, when millions of people who perceive themselves as whites have more than one drop of Black blood because of their remote Black ancestry, ${ }^{181}$ strict adherence to the one drop rule becomes problematic because it threatens the maintenance of white racial identity. One way to alleviate the problem is through the use of other symbols that correlate with racial identification, which has the effect of sending visible signals of racial identity irrespective of phenotype. The transaction costs of racial classification can thereby be reduced if geographic location correlates with racial identity.

Racial categories become more fixed and absolute, and transaction costs in maintaining these fixed categories decrease, in an environment in which the person's address or neighborhood membership becomes a proxy for race. Not only does neighborhood become a proxy for race, but it also has an internalizing effect on

${ }^{178}$ Glenn C. Loury, Free at Last? A Personal Perspective on Race and Identity in America, in LURE AND LOATHING, supra note 8, at 1, 2-3.

179 For an excellent account of passing, see Harris, supra note 8, at 1710-14.

${ }^{180}$ See id. at 1713-14 (noting that "the set of assumptions, privileges, and benefits that accompany the status of being white have become a valuable asset that whites sought to protect and that those who passed sought to attain-by fraud if necessary").

${ }^{181}$ See SOWELL, supra note 30, at 16 (stating that in the United States "more than three-quarters of the black population have at least one white ancestor, while tens of millions of whites have at least one black ancestor-and it is not uncommon for either blacks or whites to have a native American Indian ancestor"). 
its inhabitants. If inhabitants of different racial categories reside in different neighborhoods, these inhabitants can learn very early what race they are supposed to identify with and what norms and values are associated with that race. They learn to accept and value the extent of the differences because of the absence of the other.

Thus, one of the functions of segregated neighborhoods is educative, but not educative in ways that are explicitly racist. An example will perhaps clarify my thesis. Think of two cities, one racially integrated and one segregated. In a world without explicit racism, a world in which there are no theories that one race is intellectually or in any other way inferior to another race (race being based on skin color or phenotype), ${ }^{182}$ it seems quite plausible to assume that in the integrated neighborhood different skin colors would seem largely irrelevant. I find it hard to believe that one would think differently of other people in the integrated neighborhood because of their skin color. It is extremely likely that skin color in that neighborhood would be largely irrelevant, treated like eye color, ${ }^{183}$ a trait upon which no entitlement or anything else important would turn.

Compare that neighborhood with the two separate neighborhoods in which an equal number of whites and Blacks reside. Even in the absence of overt racism, I find it just as hard to believe that the inhabitants of the two neighborhoods would not notice difference, that everyone else in their neighborhood is like them (thereby creating "us") and that everyone else in the other neighborhood is different (thereby creating "them").

Having demonstrated that whiteness is a valuable property right that is protected through the maintenance of racially segregated neighborhoods, the question remains regarding what can be done to eliminate whiteness as a positive value worth defending. As I detail in Part IV, whiteness only has significant value when placed in contradistinction to Blackness. Hence, by destabilizing Blackness, whiteness likewise becomes destabilized leading, hopefully, to a world in which racial differences are minimized. In such a world, residential housing segregation would serve no value and protect no

${ }^{182}$ Cf., e.g., MURRAY \& HERRNSTEIN, supra note 28, at 276-80 (presenting data supporting the argument that whites score higher than Blacks on IQ tests).

${ }^{183}$ See Wasserstrom, supra note 9, at 604 ("A nonracist society would be one in which the race of an individual would be the functional equivalent of the eye color of individuals in our society today. In our society no basic political rights and obligations are determined on the basis of eye color."). 
interest. Before we discuss how we would secure such a world, however, we must address the failure of traditional approaches to eliminate discrimination. Those approaches, I contend in Part IV, fail because they ignore the power that race and racial identification exerts in this society. Until that power is confronted through the destabilization that I postulate, each approach will continue to fail to remediate the segregated housing patterns that in turn reify the existence and use of separate racial classifications.

\section{Destabilizing THE Conception of RACE}

One intractable puzzle that has intrigued me has to do with the persistence of a dichotomous model of racial classification in American society. When one examines how race is constructed and defined in our society, it is startling to note how racial categories neatly divide into two camps: white and Black. In this society, when it comes to matters of color, there is no in-between for individuals who are not either $100 \%$ white (if that can be defined as the total absence of Blacks as ancestors) or $100 \%$ Black (if that can be defined as the total absence of whites as ancestors). ${ }^{184}$ In particular, unlike other societies, ${ }^{185}$ current American society refuses to recognize a mixed-race or mulatto category that encompasses those individuals who are the products of a "mixed-union or marriage $^{\text {186 }}$ between a white and a Black. ${ }^{187}$ In this society,

${ }^{184}$ By focusing on Blacks, I do not mean to diminish or ignore the same duality as it applies to other classifications based on what I will loosely term as ethnicity or race. The same duality or dichotomous classificatory scheme exists with other races or ethnic classifications.

${ }^{185}$ See, e.g., Sowel., supra note 30, at 95-107 (discussing the recognition of a mixed-race category in the Caribbean and South America). Moreover, some societies made the practice of naming the offspring of mixed unions an art form. See MAGNUS MORNER, RACE MIXTURE IN THE HISTORY OF LATIN AMERICA 58 (1967). Morner presents a table ranking racial categories denoting ancestry in New Spain (Mexico) during the 18th century. The table ranks 16 such mixtures, starting with the offspring of a male Spaniard and a female Indian, which is characterized as mestizo, and concluding with the offspring of a coyote mestizo male and a mulatto female, which is characterized as ahi te estás.

${ }^{186}$ The children of mixed-race unions will no doubt increase in number as interracial unions or marriages increase. The New York Times recently reported that some offspring of interracial marriages have begun to complain that the present federal racial classification categories do not adequately reflect ethnic diversity. See Steven A. Holmes, U.S. Urged to Reflect Wider Diversity in Racial and Ethnic Classifications, N.Y. TIMES, July 8, 1994, at A18 (noting that officials expect such complaints to grow in number "in the coming years as the number of interracial marriages rises"). The report further noted that "[t]he number of interracial unions increased from 0.4 percent of all marriages in 1960 to 2.2 percent in 1992." Id.

${ }^{187}$ See, e.g., Gotanda, supra note 8 , at 25 (noting the lack of multiracial classifi- 
because of the way race is socially constructed, the offspring of a mixed union would be viewed as Black. ${ }^{188}$ Indeed, as long as there are visible traces of melanin in a person's skin that allows one to draw the conclusion that an ancestor of the individual was Black, the individual will be identified as a Black person. ${ }^{189}$

The fact that a mixed-union offspring whose physical appearance or phenotype indicates that an ancestor was or is a nonwhite is racially categorized according to the race of the nonwhite ancestor can perhaps be explained by a number of related theories having to do with protecting "whiteness" as a property right. ${ }^{190}$ Those theories have merit. The fact that "whiteness" is protected as a valuable property right, however, does not explain why other racial classifications or categories have not developed to fill the gap to identify those who are the products of mixed unions. ${ }^{191}$

This Part represents an attempt to explicate briefly how the construction of race in American society has resulted in a biracial dichotomy and to explore tentative solutions to the problems presented by this dichotomy. In particular, I argue that race as socially constructed in American society is at its most effective when

cations in the present U.S. legal system).

${ }^{183}$ Of course, this assumes that there is a sufficient population of offspring of mixed-race couples to matter. Believe it or not, at one time it was presumed (and used to support antimiscegenation statutes) that certain offspring of mixed-race couples could not produce children:

It is stated as a well authenticated fact that if the issue of a black man and a white woman, and a white man and a black woman, intermarry, they cannot possibly have any progeny, and such a fact sufficiently justifies those laws which forbid the intermarriage of blacks and whites, laying out of view other sufficient ground for such enactments.

State v. Jackson, 80 Mo. 175, 179 (1883).

${ }^{189}$ The absence of melanin in a person's skin does not, of course, mean that the person has no Black ancestors. Indeed, there are many individuals who consider themselves Black, but because of their light pigmentation are viewed by others as white, and therefore may "pass" for white in American society. See supra notes 178-81 and accompanying text (discussing the phenomenon of passing).

${ }^{190}$ See Harris, supra note 8, at 1716-21, 1758-61 (discussing past and present incentives to maintain racial purity in an attempt to secure the exclusive benefits of "whiteness"); supra part III (postulating that attempts by poor whites to cling to their property right in whiteness might partially explain why segregation is increasing among the poor despite their limited housing options).

191 In other societies, mixed-race children are treated quite differently. The one drop of blood rule that classifies the offspring of a Black and white as Black seems to be almost unique to the United States. See DAvis, supra note 159, at 81-122 (describing the variety of ways in which other societies classify mixed-race peoples, and contrasting these variations with the one drop rule's automatic assignment of the social status occupied by Blacks to persons with any Black ancestry). 
it can be manipulated to maintain a duality that entrenches the notion of "otherness" that results from a baseline of white racial purity. I contend that race and racialism (the tendency for each significant issue facing our society to be transformed into one involving race) in American society will never be eliminated or reduced until the manner in which race is categorized is radically altered to take into account the products of mixed unions in a way that recognizes their unique ethnicity and heritage. ${ }^{192}$

\section{A. Destabilizing Racial Categories}

By viewing our racial categories as simply Black and white, with white viewed as normal or good and Black viewed as different or other (and perhaps malevolently by some as bad or less than good), whites and Blacks have relied on supposedly stable categories that benefit whites at the expense of persons of color. Whites have been able to relegate all persons of color to subordinate status by reference to what they are not: white. Whiteness then becomes the defining, driving category by which others are measured. Moreover, whiteness is what I characterize as a regressive biological trait because it is defined as the absence of Black or "Blackness"; as a result, white purity is maintained when whites produce descendants with other whites. This has the effect of maintaining white racial identity and enforcing self-imposed segregation, such that whites socialize and interact only with other whites.

The attainment of the color-blind society cannot and will not occur if the current dichotomous typology of race continues to exist. In order to break down this dichotomy and deconstruct race as a harmful categorization, I contend that society should embrace, as a transitory vehicle, multiple racial categories that expressly recognize and acknowledge products of mixed-race unions. I posit that this will have the effect of destroying the Black/white dichotomy. As currently constructed, race is largely essentialistic and harmful. By developing a multiplicity of racial categories, race will ultimately be reduced to a meaningless category, as it should be.

I disagree, then, with others who believe that Blacks need to maintain the current mode of racial typology in order to harness

${ }^{192} \mathrm{My}$ model is the treatment of race in Hawaii in which race and color are largely irrelevant. See id. at 112-13. For further discussion of the treatment of race in Hawaii, see Johnson, supra note 24, at 20-21 (discussing how the one drop rule does not operate in Hawaii as it does elsewhere in the United States because of that state's history, population mix, and cultural norms). 
and maintain their political strength. ${ }^{193}$ I conclude that although that particular goal may be accomplished in the short term, it comes at a detrimental, long-term cost. The express adoption of multiracial categories, however, is for the long-term benefit of eliminating race and racism in this society. In the short term, alliances must be made across these multiracial boundaries in order to maintain and increase political strength. This short-term strategy of maintaining and perfecting alliances seems to be quite attainable given the commonality of interests that cut across these multiracial lines.

What is revealing about the biracial composition of American society is how it elevates whiteness, or race, over ethnicity as a unifying feature of the dominant group in American society. At the same time, it constrains all those who are not purely white, either visibly, through ancestry, or both, to a subordinate status as a minority. In reality, of course, no majority group exists. Whiteness, as a racial category, becomes important and defining in this society for two reasons. First, a substantial percentage of the population is not white-they are Black or some racial identification other than white. ${ }^{194}$ It is only the existence of Blacks and this country's historical treatment of Blacks that makes whiteness so defining and important. Second, this country's original (and to a lesser degree, continuing) status as a melting pot for immigrants from Europe, coupled with its democratic ideals, has created a hodgepodge not only of races, but also of ethnic heterogeneity. This ethnic heterogeneity, if allowed to flourish, may have the effect of destabilizing whiteness as a property right in the same way that a multiracial taxonomy does. If whiteness and Blackness are removed as identifiers, and ethnicity substituted, America looks remarkably diverse and pluralistic, with no one group dominating over any other group.

Race is the factor that masks the diversity that is American ethnic make-up. Whites are able to minimize and view as secondary their ethnicity due to the presence and opposite definition of

193 The U.S. Census Bureau announced plans for 1996 to offer "multiracial" as an option in indicating one's race, but minority groups responded negatively. See Hanna Rosin, Boxed in, NEw REPUBLIC, Jan. 31, 1994, at 12 ("The prospect that the new category would dilute their statistical strength had [minority groups] clamoring in defense of the status quo.").

${ }^{194}$ According to the Statistical Abstract of the United States 1994, in 1992 approximately $42,170,000$ out of a total of $255,082,000$ Americans were not white. See U.S. BUREAU OF THE CENSUS, supra note 144, at 17. 
Blacks. White only has meaning when Blacks are prevalent in society. ${ }^{195}$ Thus, the biracial classification or taxonomy not only has the effect of monolithizing Blacks and the Black experience, it has the related effect of unifying whites and submerging ethnic differences that, if recognized, would deconstruct and destroy racism's base elements-a sense of identity of "us" versus "them." Were these ethnic differences recognized, ethnic identity would become important for a sense of self.

What is puzzling and revealing is the way ethnicity functions in our society to differentiate whites into various subgroups, whereas Blacks apparently either lack ethnicity or their ethnicity is so correlated with race that the two are coterminous and indistinguishable. Race and ethnicity are one when the individual is an American Black. ${ }^{196}$

If ethnicity is correlated with a country of national origin, ${ }^{197}$ then part of what slavery apparently accomplished, through its eradication of the slave's individual identity as an equal or a person and its lack of respect for that slave's heritage and country of origin, is the obliteration of the ethnicity of the descendants of those original slaves. The obliteration of the slave's geographic or tribal identity, which today could constitute ethnicity, was further hastened by forced miscegenation, creating what some may characterize as an indigenous race in the United States that came into being only as a byproduct of slavery. ${ }^{198}$

195 Whether this society would be riven by ethnic strife, $a$ l $a$ the former Yugoslavia, if the United States did not have a significant Black population is beyond the scope of this Article. It is nevertheless interesting to speculate about this issue. I come to the conclusion that no such strife would exist because of the relative historical youth of this country and the fact that, to some degree, with the exception of Native Americans, all ethnic groups are immigrant groups. I do believe, however, that ethnic tensions would be exacerbated.

${ }^{196}$ I highlight here American Black because of the plausible assertion that Blacks from other countries are treated differently, that is, better than American Blacks. That fact may reflect the reality that foreign-born Blacks, like white Americans, may have an ethnic identity based on their nationality that American Blacks do not have. For further discussion of this issue, see Jolnnson, supra note 24, at $32 \mathrm{n.69}$ (describing how stereotypes and racism against American Blacks are not only race based, but culturally and environmentally based as wcll).

193 See MICHAEL OMI \& HOWARD WINANT, RACIAL FORMATION IN THE UNITED STATES FROM THE 1960S TO THE 1980S, at 15 (1986) ("Race was but one of a number of determinants of ethnic group identity or ethnicity. Ethnicity itself was understood as the result of a group formation process based on culture and descent." ).

${ }^{198}$ See Johnson, supra note 5, at 1415 (discussing the theory that Black Americans represent a new ethnic group indigenous to North America similar to the Native Americans but dissimilar because they were forcibly brought here and created here 
Consequently, society has constructed a biracial taxonomy to differentiate between whites and Blacks, while simultaneously constructing ethnicity as a differentiating classificatory scheme from which Blacks are excluded. Differences that matter among whites are relegated to an inconsequential status among Blacks. As Michael Omi and Howard Winant argue:

In fact, with rare exceptions, ethnicity theory isn't very interested in ethnicity among blacks. The ethnicity approach views blacks as one ethnic group among others. It does not consider national origin, religion, language, or cultural differences among blacks, as it does among whites, as sources of ethnicity. ... There is, in fact, a subtly racist element in this substitution-in which whites are seen as variegated in terms of group identities, but blacks "all look alike. ${ }^{\text {199 }}$

For Blacks, therefore, ethnicity is conflated with race. This conflation causes all Blacks to be viewed as belonging to the same ethnic group, whether their ancestors are from the Ibo tribe in Nigeria or the Banta people who populate Zambia and Zimbabwe. Similarly, if "intermediary" ancestors of today's Blacks originated in Brazil or an island in the Caribbean, that factor too is deemed irrelevant. In addition, to the extent Blacks have settled in different regions and have undertaken different lifestyles, those differences have been minimized or subsumed by racial identification of Blacks qua Black. This overriding tendency to treat race as a unifying characteristic negates any differences that might exist or develop between Blacks based either on ancestors' point of origin or current geographic location.

What is problematic about this conflation is what it portends for the way whites and Blacks are viewed in this society and interpreted by others. Ethnicity is not only something that is learned and internalized as a member of a group; it is also a characteristic or trait that must be communicated from the ethnic group member to the individual doing the categorization. ${ }^{200}$ In this respect, ethnicity is

rather than being found and separated from their dominion over the land).

199 OMI \& WINANT, supra note 197, at 23.

${ }^{200}$ For a discussion of why this is so, except perhaps on the margin where ethnic identity is visible and serves a function similar to that of race, see Johnson, supra note 24. In that article, I argue that, with rare exceptions, ethnicity is communicated or learned through interaction between parties because most ethnic groups in the United States trace their ancestry to Northern Europe and thus are largely indistinguishable by appearance or phenotype. The person on the margin, whose ethnicity is visible and therefore not merely communicated or learned, usually most 
different from race because race is something that is typically visibly ascertainable and recognizable. More importantly, because ethnicity is something that is learned and communicated, it is something that can be changed and concealed or disguised. Race, on the contrary, because of its visible and instantaneous recognition, cannot so easily be manipulated. ${ }^{201}$

Moreover, because of the pliability of ethnic classification, ethnicity is largely something that can be embraced, ignored, or changed at the whim of the individual. Ethnic identification does not preclude assimilation and passing into larger white society.

resembles the stereotypes associated with the particular ethnic group. For example, a very large man with fair skin, blue eyes, and blond hair may correctly-but not always-be identified as German or Teutonic.

201 The phenomenon of "passing," see supra notes 178-81, demonstrates the futility of racial classificatory schemes premised on biologic arguments and illustrates the strength of the claim that it is ethnicity and not race that should govern categorization.

One may look white and be Black, whereas conversely one may look Black and be white. This last phrase-that one may look Black and be white-caused me to pause as I wrote it. Although it is easy to conceive of situations where Blacks have passed for whites, it is hard to think of any rational basis why someone would look Black and be white. But clearly there are individuals who are the products of two visibly white parents but who, because of the ancestry of their parents (one parent had, for example, a Black grandmother and unbeknownst to her, her mother passed as white and never informed the daughter), are visibly Black. The hesitancy I had in writing the phrase "one may look Black and be white" has, I think, to do with the way that we consider whiteness as superior, as a property right that defines Blackness as inferior. See supra part III. We can think of increasingly lighter-hued peregrinations of Black parents producing lighter (what some perceive to be better) children. For some that represents the optimal strategy in marriage-marrying to lighten one's children's skin color. I have characterized this phenomenon as "color-consciousness." See Johnson, supra note 24, at 28-34 (describing how Blacks, by imposing their own scheme of "color-consciousness" have internalized their own subordinated position and elevated whiteness to a property right). Others have referred to it as "colorism." Itabari Njeri, Sushi and Grils: Ethnic Identily and Conflict in a Newly Multicultured America, in LURE AND LOATHING, supra note 8, at 13, 16 (citing the work of Alice Walker).

But it is hard to fathom white parents producing Black children. That has the impact and effect of destroying the alleged purity that is whiteness. If whiteness can beget Blackness, how then is whiteness defined? The entire dichotomy of racial classification disappears. It would not surprise me, then, that the reason that one does not hear of instances in which two visibly white parents beget a visibly Black child is that such a child is cosmetically altered in some fashion to achieve visible whiteness or the mother (or the father as the case may be) is reclassified as Black to explain the presence of the Black child. In this case, the production of the Black child has the odd and probably unintended effect of causing the parent to be reclassified so as to conform to our social construction of race, in which Blacks can aspire to whiteness and perhaps ultimately produce it, but whites cannot produce Blackness. 
Thus, an Italian or a Polish person may have her name voluntarily or involuntarily anglicized so as to obscure her ethnic origins. That individual could in certain contexts choose to proclaim, minimize, or repudiate her ethnic heritage; racial identification cannot be manipulated in this way. Race, like gender, is (to a large extent) truly immutable, whereas ethnicity is more chameleon-like and changeable. As a result, ethnicity-sometimes something to be proud of and other times something to run from-is not as stigmatizing as race.

If race functioned as ethnicity currently functions in our society, racism and the societal ills it creates would not exist. Furthermore, the negative attributions associated with being Black or Blackness ${ }^{202}$ in this society could not exist to any significant degree because racial identifications would not be made. Consequently, if race acted as ethnicity, race would be a relatively harmless category.

Suffice it to say, my basic contention is that racial identification must be destabilized and made fluid akin to ethnic categories. ${ }^{203}$ By destabilizing racial classification through first recognizing a racial category denominated as "other," it is hoped that the boundaries of racial identification will dissolve, and ethnic identity, with its associated positive attributes, will be recognized as the primary paradigm by which to identify and classify individuals. Moving from the visual (racial identification) to the learned (ethnic identification) will have positive results, but not without the costs associated with the transition from a world in which all persons who are not white are categorized as Black or other. ${ }^{204}$

\section{B. Reviving Antidiscrimination Law Through Destabilization}

As noted above, I presume that both what I characterize as "market" and "interventionist" models fail to adequately correct and address the issues raised by housing discrimination. Yet I agree that discrimination in both housing and employment are normatively

${ }^{202}$ See supra notes 65-67 and accompanying text.

${ }^{203}$ Elsewhere I argue that the answer lies in destabilizing the trademark of Black and Blackness, which will have the effect of destabilizing racial identification and permitting ethnic identification to take hold with all of the attendant benefits. That is the subject of another article and cannot be fully explored herein. See Johnson, supra note 24, at 49-51 (describing how destabilization of the trademark of Blackness can weaken negative perceptions and improve positive perceptions of Blacks).

${ }^{204}$ As noted previously, many Blacks have objected to the development of a multiracial box on the census form because it allegedly minimizes the heretofore monolithic Black political power. See supra note 193 and accompanying text. 
wrong from both a moral perspective ${ }^{205}$ and an economic perspective. ${ }^{206}$ The moral perspective is intuitively easier to grasp and descriptively much harder to allege (indeed, it requires the sort of exegesis that expert philosophers must make and thus lies beyond the scope of this Article).

The less accessible, and perhaps more concrete, argument that discrimination in housing is inefficient and should therefore be the subject of regulation has been concisely made:

By analogy to theft, the benefit from prohibiting a form of discrimination is to prevent the waste of resources invested in such discrimination as a means of acquiring (confiscating) status. When theft is prohibited, the primary alternative by which the former thief can make material gains is ... to engage in productive activity. The argument for laws prohibiting subordination as a means of acquiring status is exactly parallel: such laws induce people to switch to socially productive, or at least socially benign, means of acquiring status (either at the individual or group level)... . The same argument can be made for prohibiting private discrimination in certain key areas, beginning, for example, with employment and housing. ... Effectively prohibiting employment and housing discrimination deprives whites of their most productive private means of subordination, thereby lowering the resources invested in this wasteful confiscatory activity. ${ }^{207}$

Moreover, antidiscrimination laws result in less discrimination by encouraging integration among different groups. When whites and Blacks reside and work in integrated environments, "crossmembership" in groups will be fostered. That cross-membership, or what I characterize as multiple-membership in groups, will inevitably lead to a lessening of discrimination. ${ }^{208}$

What has been ignored to date are the benefits that would ensue if group membership itself were destabilized. It stands to reason that if group identity were destabilized so as either to increase the number and types of cross-memberships through the recognition of multiracial categories ${ }^{209}$ or to make group membership indetermi-

${ }^{205}$ See RAWLS, supra note 125, at 75 (arguing that the "uhigher expectations of those better situated are just if and only if they work as part of a scheme which improves the expectations of the least advantaged members of society").

${ }^{206}$ See supra parts II.A-D.

${ }^{207}$ McAdams, supra note 21, at 105-06 (footnotes omitted).

${ }^{208}$ See id. at 106-07 (discussing how "cross-membership" will eliminate economic incentives to subordinate members of other groups).

${ }^{209}$ To the extent that racial identification remains stable, having multiracial groups will increase cross-membership in groups. Both whites and Blacks will have to lessen 
nate, discrimination aimed at producing group status would decrease. ${ }^{20}$ What is important to recognize at this point is that antidiscrimination law will remain an ineffective tool for combating inefficient and morally impermissible racial discrimination in housing if the law is based on dichotomous and inconsistent premises. The law cannot advocate an antidiscrimination principle in which race and racial identification are said to be irrelevant and at the same time explicitly promote racial classifications that produce group status or esteem through fixed racial identities. The inevitable result is dissonance between the stated ideal and the practical reality.

\section{CONCLUSION}

The standard explanations given for why Blacks find themselves in ghettos only partially explain the patterns of segregation in American society. Thus, although race and poverty are clearly causative factors leading to the creation and maintenance of ghettos in American society, these factors, alone and in harmony (at least as traditionally viewed in harmony), do not explain the total absence of integration among the poor. Poverty alone cannot explain why Blacks and whites inhabit separate neighborhoods because of the significant overlap of white and Black poor. Race alone cannot explain why poor whites are so averse to living in integrated neighborhoods when their impoverished state should limit their choices. More importantly, the experience of other minority and immigrant groups belies the notion that race and racism play a significant role in maintaining segregated neighborhoods.

To paraphrase Cornel West, race, unfortunately, continues to matter in American society. ${ }^{211}$ The biracial categorization of race

their discrimination against the other group because such discrimination, when applied to a member of a multiracial group, will necessarily result in discrimination against their own favored group. The offspring of a Black-white union will not discriminate against either Blacks or whites because to do so would lower that individual's self-esteem. At the very least, it would result in self-abnegation.

${ }^{210}$ The benefits and costs of the recognition of multiple racial categories and the destabilization of current group categories is the subject of yet another article. See Johnson, supra note 24, at 24-27 (attempting to explicate the reasons why race in American society has been constructed as a biracial, Black/white dichotomy).

${ }^{211}$ See, e.g., West, supra note 30 (1993) (arguing that a serious discussion of race in America must begin not with the problems of black people but with the flaws of American society-flaws rooted in historic inequalities and longstanding cultural stereotypes-and analyzing issues such as the new black conservatism, black-Jewish relations, and myths about black sexuality). 
is a relic of an antebellum system of slavery that should have been discarded long ago, when slavery itself was abolished. The dichotomous classification of race, however, has been reinforced in American society for over three centuries. This biracial categorization continues to serve the same role that it did in slavery-to mark and define those who were part of the dominant, privileged class, while branding those who are subordinate and on the bottom. As long as this biracial marking continues to occur, progress in race relations, including housing, will be impeded.

Consequently, I contend that the exclusivity of the two marks of "white" and "Black" should be deconstructed and destroyed. It is the intersection of race and poverty that creates a property right in whiteness for poor whites that consigns Blacks to segregated ghettos. Moreover, because we no longer wage a War on Poverty that can or will be used to raise both poor whites and Blacks to a socioeconomic level in which whiteness as a property right is irrelevant, the only viable way to attack segregation is by attacking the stable classifications of race.

Notwithstanding a wealth of scientific and other data that proves that there is no such thing as a "white" race or a "Black" race, American society and law perpetuates the social construction of such categories by recognizing them as fixed and stable. My tentative conclusion is that the old categories, given the baggage they carry, must be destabilized and discarded. In their place, I contend we should create a society in which multiracial categories are encouraged and recognized. That will reduce the importance of racial identification and racism in our society. Unfortunately, it may have the short-term effect of reducing the political strengths of the currently constructed racial groups and creating a society in which racial categories soon become irrelevant. ${ }^{212}$ A world without race, or at least a biracial conception of race, is frightening to some and rightfully so. The unknown always represents a challenge, a challenge that we should begin to analyze and address.

${ }^{212}$ But $c f$. Rosin, supra note 193, at 14. Despite the potential gains in accuracy a multiracial census category could achieve, "Census statisticians claim it is too broad to be useful. 'Who's in there? You could fit all of the U.S. in that category,' says Juanita Tama Lott, a Census consultant. 'In order to do statistical analysis we have to have mutually exclusive categories." Id. 